\title{
COVID-19 vaccine therapeutic trials review: published results and registered protocols
}

\author{
Molka Osman ${ }^{1} \mathbb{0}$, Mouna Safer ${ }^{2}$, Aicha Hechaichi ${ }^{2}$, Hejer Letaief ${ }^{1}$, Sonia Dhaouadi ${ }^{1}$, Chahida Harizi ${ }^{3}$, Hamida Ben Salah \\ ', Sondes Derouiche', Leila Bouabid', Souha Bougatef ${ }^{1}$, Nissaf Ben Alaya Bouafif ${ }^{2}$ \\ ${ }^{1}$ National Observatory of New and Emerging Diseases, Tunis, Tunisia, ${ }^{2}$ National Observatory of New and Emerging Diseases, Tunis, Tunisia; \\ University of Tunis El Manar, Faculty of Medicine of Tunis, Tunisia, ${ }^{3}$ University of Tunis El Manar, Faculty of Medicine of Tunis, Tunisia; Department of \\ Epidemiology and Statistics, Abderrahman Mami Hospital, Ariana, Tunisia \\ Keywords: covid-19, clinical trials as topic, clinical trial protocols as topic, covid-19 vaccines, vaccine development, sars-cov-2 \\ https://doi.org/10.29392/001c.21369
}

\section{Journal of Global Health Reports}

Vol. 5, 2021

\begin{abstract}
Background
Since the emerging of Coronavirus disease 2019 (COVID-19) in late 2019 and the World Health Organization (WHO) declaring it as a pandemic, a race to develop a vaccine against COVID-19 has started worldwide and therefore huge efforts and resources have been put into achieving it. This review summarizes COVID-19 vaccines in phase III and IV.
\end{abstract}

\section{Methods}

A review of the scientific literature was conducted using the medical subject heading (MeSH) word "COVID-19 vaccines" on PubMed and the words "COVID-19", "SARS-CoV-2" and "vaccine" on ClinicalTrials.gov as of January 24, 2021. The published WHO reports on candidate COVID-19 vaccines were reviewed. For clinical trials, only phase III and IV COVID-19 vaccines were included.

\section{Results \\ Of the 1300 citations identified on January 24, 2021, 81 were eligible and included in this review. According to WHO report of January 22, 2021, there were 237 candidates vaccines in development and among them 64 vaccines were in advanced stages of development. On the same date, on ClinicalTrials.gov, there were 66 registered COVID-19 vaccines clinical trials on phase III and IV. Thirty seven were new candidates vaccines on phase III, 23 were BCG vaccines including five on phase VI, three were measles vaccines on phase III and three were polio vaccines (one on phase VI and one on phase III).}

\section{Conclusions}

Despite safe and effective vaccines are available many challenges remain including logistic difficulties concerning mass production, supply, storage, cold chain, administration at community level and equitable distribution to the most vulnerable populations. Hence the need to continue preventive measures including, hand wash, wearing mask, cough and sneeze etiquette and social distancing.

Coronavirus disease 2019 (COVID-19), an infection caused by severe acute respiratory syndrome coronavirus-2 (SARS-CoV-2), was first reported in December 2019, in Wuhan, province of Hubei in China. Since then, it has become one of the world's toughest health problems. The World Health Organization (WHO) announced on January 30, 2020 that the COVID-19 epidemic was a public health emergency of international concern and on March 20, 2020, that it was a pandemic. ${ }^{1}$ As of January 24,2021 , more than 97 million cases of COVID-19 have been reported worldwide, causing more than 2 million deaths. ${ }^{2}$ In just a few months, huge efforts have been made and several vaccines are in development.
This review summarizes COVID-19 vaccines clinical trials in phase III and IV and all published clinical trials' results.

\section{METHODS}

A review of the scientific literature was conducted with the aim to study the therapeutic trials of vaccines against the coronavirus disease 2019 (COVID-19). To this end, as of January 24, 2021 a search for articles published on PubMed using the Mesh word "COVID-19 Vaccine", as well as a search for protocols registered on ClinicalTrials.gov by combining the words "COVID-19", "SARS-CoV-2" and "Vaccine" was 


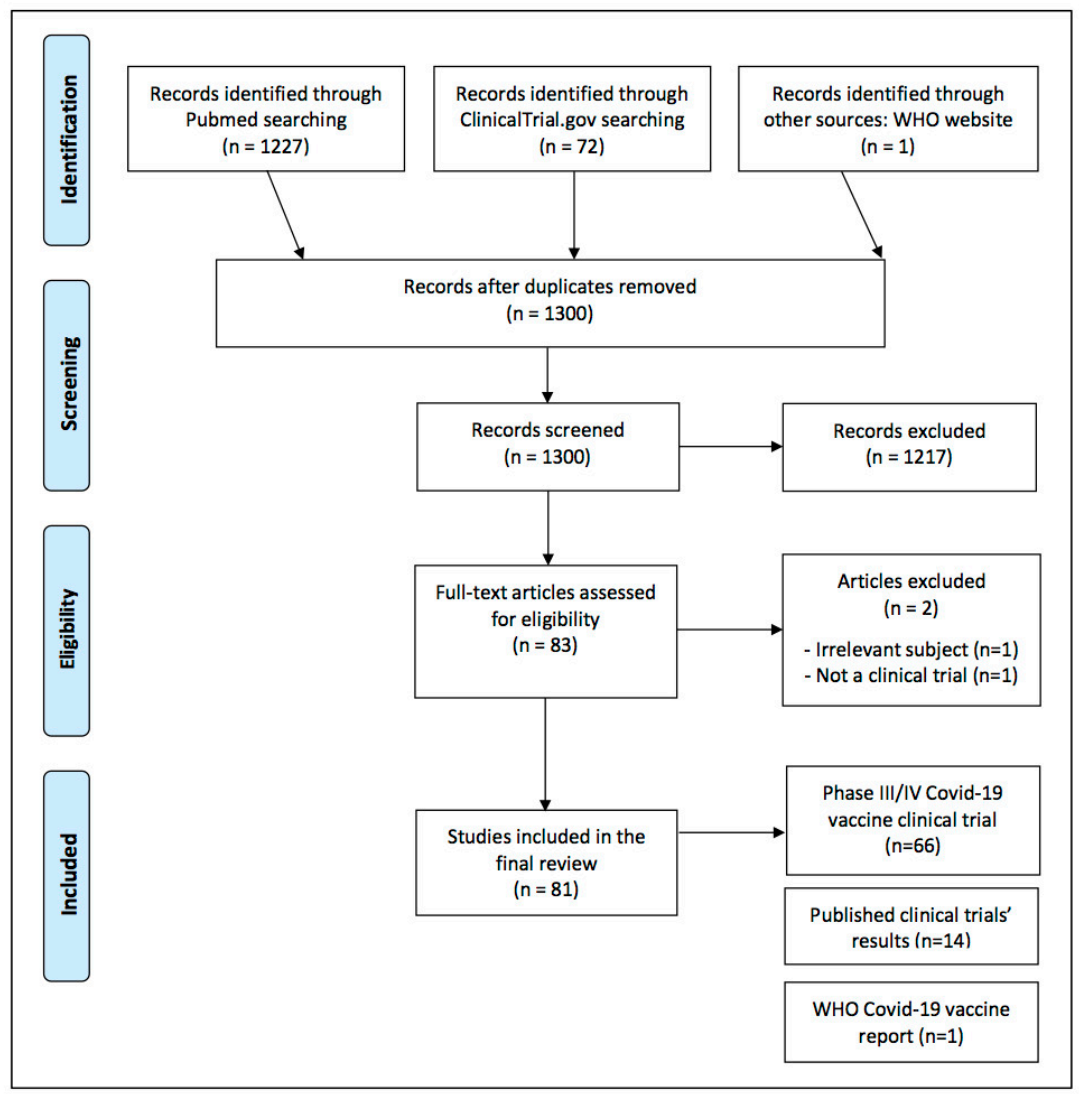

Figure 1: PRISMA flow chart.

made. The published WHO reports on candidate COVID-19 vaccines were reviewed. At first, citations that were not in French or in English and not a clinical trial or randomized controlled trial were excluded. Then, those with irrelevant information or subject and studies with focus other than COVID-19 vaccine development or clinical trial were excluded. For registered protocols, those in relation with drugs were excluded.

\section{RESULTS}

\section{INCLUDED CITATIONS IN THE COVID-19 VACCINE THERAPEUTIC TRIALS REVIEW}

On PubMed, 1227 articles were initially found, out of which 16 articles were selected. In the end, 14 articles were selected. On ClinicalTrials.gov, as of January 24, 2021, 72 phase III or IV, clinical trial protocols, encompassing vaccines and treatments have been identified initially, of which 66 for COVID-19 vaccines have been selected (Figure 1).

\section{WHO COVID-19 VACCINE REPORT AS OF JANUARY 24, 2021}

According to the WHO COVID-19 vaccine report of January 22,2021 , there were 237 vaccines. More specifically, 64 vaccines were in clinical evaluation (16 in phase III, 6 in phase
II / III, 5 in phase II, 19 in phase I / II and 18 in phase I) and 173 vaccines were in preclinical evaluation. ${ }^{3}$

\section{PHASE III AND IV CLINICAL TRIALS}

\section{NEW COVID-19 VACCINES}

Vaccine development, determined by clinical trials, is divided into three phases between preclinical exploratory work and vaccine approval (Box 1). ${ }^{4}$

Most of the candidate COVID-19 vaccines are based on the $S$ antigen in the form of inactivated vaccines, subunit vaccines, viral vector vaccines, and DNA or mRNA 3 nucleic acid vaccines. 5

In this review, the focus will be on clinical trials for vaccines in phase III and above.

For the new candidates COVID-19 vaccines, there were 37 clinical trials on Phase III, of which one clinical trial was simultaneously in phase I/II/III and eight in phase II/III. Eleven (30\%) clinical trials concerned inactivated vaccines and 30 (81\%) clinical trials used two doses. Six clinical trials were active and not recruiting while 23 were still recruiting participants. The number of participants to be recruited varied from 100 to 60,000 (Table 1). 
Table 1: Candidate vaccines against COVID-19 in phase III as of January 24, 2021

\begin{tabular}{|c|c|c|c|c|c|c|c|c|}
\hline $\begin{array}{c}\text { COVID-19 vaccine } \\
\text { developer / } \\
\text { Manufacturer }\end{array}$ & $\begin{array}{l}\text { Type of } \\
\text { vaccine }\end{array}$ & $\begin{array}{l}\text { Number } \\
\text { of doses }\end{array}$ & $\begin{array}{c}\text { Timing } \\
\text { of } \\
\text { doses }\end{array}$ & $\begin{array}{c}\text { Route of } \\
\text { administration }\end{array}$ & Country & $\begin{array}{l}\text { Recruitment } \\
\text { status }\end{array}$ & $\begin{array}{c}\text { Estimated } \\
\text { number of } \\
\text { participants }\end{array}$ & Description of the clinical trial \\
\hline$\underset{6}{\text { BioNTech SE/Pfizer }}$ & $\begin{array}{l}\text { RNA (3 } 3 \text { LNP- } \\
\text { mRNA) }\end{array}$ & 2 & $\begin{array}{l}\text { Day } \\
0 \text { and } \\
\text { Day } \\
21\end{array}$ & IM & $\begin{array}{l}\text { Argentina, } \\
\text { Brazil, } \\
\text { Germany, } \\
\text { South } \\
\text { Africa, } \\
\text { Turkey, } \\
\text { United } \\
\text { States }\end{array}$ & $\begin{array}{l}\text { Active, not } \\
\text { Recruiting }\end{array}$ & 43998 & $\begin{array}{l}\text { Phase I/II/III, randomized, triple-blind (participant, care provider, } \\
\text { investigator), placebo-controlled clinical trial with participants } \\
\text { randomly assigned to placebo and experimental vaccine cohorts } \\
\text { (BNT162b1 and BNT162b2) in healthy individuals aged } 12 \text { years and } \\
\text { over The study consists of } 2 \text { parts: } \\
\qquad \begin{array}{l}\text { • Phase I: to identify the preferred candidate vaccine (s) and } \\
\text { dose levels } \\
\text { • Phase II/III: an enlarged cohort and an efficiency part }\end{array} \\
\text { The candidate vaccine selected for Phase II/III evaluation was } \\
\text { BNT162b2 in medium dose ClinicalTrials.gov Identifier: } \\
\text { NCT04368728 Estimated Study Completion Date : January } 31,2023\end{array}$ \\
\hline $\begin{array}{l}\text { Gamaleya Research } \\
\text { Institute of } \\
\text { Epidemiology and } \\
\text { Microbiology, } \\
\text { Health Ministry of } \\
\text { the Russian } \\
\text { Federation }\end{array}$ & $\begin{array}{l}\text { Combined } \\
\text { viral vector } \\
\text { (Adenovirus } \\
\text { (rAd26-S+ } \\
\text { rAd5-S)) }\end{array}$ & 2 & $\begin{array}{l}\text { Day } \\
\text { Oand } \\
\text { Day } \\
21\end{array}$ & IM & $\begin{array}{l}\text { Russian } \\
\text { Federation }\end{array}$ & $\begin{array}{l}\text { Active, not } \\
\text { recruiting }\end{array}$ & 33758 & $\begin{array}{l}\text { Multicenter, randomized, double-blind, placebo-controlled clinical trial } \\
\text { in healthy adults aged } 18 \text { to } 111 \text { years. After screening, they will be } \\
\text { randomized (3:1) into two groups, a reference group of } 10,000 \\
\text { volunteers receiving placebo and a study group of } 30,000 \text { volunteers } \\
\text { receiving the Gam-COVID-Vac combined vector vaccine. The trial } \\
\text { subjects will be randomized into five age strata: } 18-30,31-40,41-50, \\
51-60 \text {, and } 60+\text { years. ClinicalTrials.gov Identifier: } \text { NCTO4530396 } \\
\text { Estimated Study Completion Date : May 1, } 2021\end{array}$ \\
\hline $\begin{array}{l}\text { ModernaTX/NIAD } \\
8\end{array}$ & $\begin{array}{l}\text { RNA } \\
\text { (Encapsulated } \\
\text { LNP-mRNA) }\end{array}$ & 2 & $\begin{array}{l}\text { Day } \\
\text { Oand } \\
\text { Day } \\
28\end{array}$ & IM & $\begin{array}{l}\text { United } \\
\text { States }\end{array}$ & $\begin{array}{l}\text { Active, not } \\
\text { recruiting }\end{array}$ & 30000 & $\begin{array}{l}\text { Quadruple-blind (participant, caregiver, investigator, outcome } \\
\text { assessor), placebo-controlled randomized clinical trial with participants } \\
\text { randomly assigned to placebo and experimental vaccine cohorts } \\
\text { (mRNA-1273) in healthy adults aged } 18 \text { years and older. } \\
\text { ClinicalTrials.gov Identifier : NCTO4470427 Estimated Study } \\
\text { Completion Date : October } 27,2022\end{array}$ \\
\hline $\begin{array}{l}\text { Laboratory Elea } \\
\text { Phoenix S.A } 9\end{array}$ & Inactivated & 2 & $\begin{array}{l}\text { Day } 0 \\
\text { and } \\
\text { Day } \\
21\end{array}$ & IM & Argentina & $\begin{array}{l}\text { Active not } \\
\text { recruiting }\end{array}$ & 3000 & $\begin{array}{l}\text { Double-blind, placebo-controlled clinical trial with randomly (1:1) } \\
\text { participants assigned to placebo and experimental (Vero cell) vaccine } \\
\text { cohorts in healthy adults aged } 18 \text { to } 85 \text { years. } \\
\text { ClinicalTrials.gov Identifier : NCT04560881 Estimated Study } \\
\text { Completion Date : December 1, } 2021\end{array}$ \\
\hline NPO Petrovax ${ }^{10}$ & $\begin{array}{l}\text { Adenovirus } \\
\text { type } 5 \text { Vector }\end{array}$ & 1 & Day 0 & IM & $\begin{array}{c}\text { Russian } \\
\text { Federation }\end{array}$ & $\begin{array}{l}\text { Active, not } \\
\text { recruiting }\end{array}$ & 500 & $\begin{array}{l}\text { Randomized, multicenter, quadruple-blind (participant, care provider, } \\
\text { investigator, outcome assessor), placebo-controlled clinical trial with } \\
\text { randomized ( } 3: 1) \text { participants assigned in placebo }(n=125) \text { and } \\
\text { experimental vaccine ( } n=375 \text { ) cohorts in adults in good health aged } 18 \\
\text { to } 85 \text { years. ClinicalTrials.gov Identifier : NCTO4540419 Estimated } \\
\text { Study Completion Date : July 31, } 2021\end{array}$ \\
\hline $\begin{array}{l}\text { Gamaleya Research } \\
\text { Institute of } \\
\text { Epidemiology and } \\
\text { Microbiology, } \\
\text { Health Ministry of } \\
\text { the Russian } \\
\text { Federation } 11\end{array}$ & $\begin{array}{l}\text { Combined } \\
\text { viral vector } \\
\text { (Adenovirus } \\
\text { (rAd26-S+ } \\
\text { rAd5-S)) }\end{array}$ & 2 & $\begin{array}{l}\text { Day } 0 \\
\text { and } \\
\text { Day } \\
21\end{array}$ & IM & Belarus & $\begin{array}{l}\text { Active, not } \\
\text { Recruiting }\end{array}$ & 100 & $\begin{array}{l}\text { Double-blind, placebo-controlled clinical trial with participants } \\
\text { randomly assigned ( }(3: 1) \text { to placebo }(n=25) \text { and experimental (GAM- } \\
\text { COVID-Vac; } n=75) \text { vaccine cohorts in healthy adults aged from } 18 \text { to } 60 \\
\text { years old. ClinicalTrials.gov Identifier: NCT04564716 Estimated } \\
\text { Study Completion Date : April 10, } 2021\end{array}$ \\
\hline
\end{tabular}




\begin{tabular}{|c|c|c|c|c|c|c|c|c|}
\hline $\begin{array}{c}\text { COVID-19 vaccine } \\
\text { developer / } \\
\text { Manufacturer }\end{array}$ & $\begin{array}{l}\text { Type of } \\
\text { vaccine }\end{array}$ & $\begin{array}{l}\text { Number } \\
\text { of doses }\end{array}$ & $\begin{array}{l}\text { Timing } \\
\text { of } \\
\text { doses }\end{array}$ & $\begin{array}{c}\text { Route of } \\
\text { administration }\end{array}$ & Country & $\begin{array}{l}\text { Recruitment } \\
\text { status }\end{array}$ & $\begin{array}{c}\text { Estimated } \\
\text { number of } \\
\text { participants }\end{array}$ & Description of the clinical trial \\
\hline $\begin{array}{l}\text { Janssen Vaccines \& } \\
\text { Prevention B.V } 12\end{array}$ & $\begin{array}{l}\text { Non- } \\
\text { replicating } \\
\text { viral vector }\end{array}$ & 1 & Day 0 & IM & $\begin{array}{l}\text { Argentina, } \\
\text { Brazil, Chile, } \\
\text { Colombia, } \\
\text { Mexico, } \\
\text { Peru, South } \\
\text { Africa, } \\
\text { United } \\
\text { States }\end{array}$ & Recruiting & 60000 & $\begin{array}{l}\text { A randomized, quadruple-blind (participant, caregiver, investigator, } \\
\text { outcome assessor), placebo-controlled clinical trial with participants } \\
\text { randomly assigned to placebo and experimental vaccine (Ad26.COV2.S) } \\
\text { cohorts in healthy adults aged } 18 \text { and older. } \\
\text { ClinicalTrials.gov Identifier: } \mathrm{NCTO4505722} \text { Estimated Study } \\
\text { Completion Date: March 10, } 2023\end{array}$ \\
\hline $\begin{array}{l}\text { China National } \\
\text { Biotec Group } \\
\text { Company Limited } \\
13\end{array}$ & Inactivated & 2 & $\begin{array}{l}\text { Day } 0 \\
\text { and } \\
\text { Day } \\
21\end{array}$ & IM & $\begin{array}{l}\text { Bahrain, } \\
\text { Egypt, } \\
\text { Jordan, } \\
\text { United Arab } \\
\text { Emirates, }\end{array}$ & Recruiting & 45000 & $\begin{array}{l}\text { Double-blind, placebo-controlled clinical trial with participants } \\
\text { randomly assigned (1:1:1) to one cohort of placebo vaccine and two } \\
\text { cohorts of experimental vaccine (Vero Cell) in healthy adults aged } 18 \\
\text { years and older. ClinicalTrials.gov Identifier: NCT04510207 Estimated } \\
\text { Study Completion Date : September 16, } 2021\end{array}$ \\
\hline $\begin{array}{l}\text { CanSino Biologics } \\
\text { Inc/Beijing } \\
\text { Institute of } \\
\text { Biotechnology } 14\end{array}$ & $\begin{array}{l}\text { Non- } \\
\text { replicating } \\
\text { viral vector }\end{array}$ & 1 & Day 0 & IM & $\begin{array}{l}\text { Argentina, } \\
\text { Chile, } \\
\text { Mexico, } \\
\text { Pakistan, } \\
\text { Russian } \\
\text { Federation }\end{array}$ & Recruiting & 40000 & $\begin{array}{l}\text { Double-blind, placebo-controlled clinical trial with randomly (1:1) } \\
\text { participants assigned to placebo and experimental vaccine (Adenovirus } \\
\text { Vector Type 5) cohorts in healthy adults aged } 18 \text { years and older. } \\
\text { ClinicalTrials.gov Identifier: NCT04526990 Estimated Study } \\
\text { Completion Date: January } 30,2022\end{array}$ \\
\hline CureVac AG ${ }^{15}$ & mRNA & 2 & $\begin{array}{l}\text { Day } 0 \\
\text { and } \\
\text { Day } \\
28\end{array}$ & IM & $\begin{array}{l}\text { Belgium, } \\
\text { Germany, } \\
\text { Netherlands }\end{array}$ & Recruiting & 36500 & $\begin{array}{l}\text { A phase IIb/III, multicenter, randomized, double-blind, placebo- } \\
\text { controlled clinical trial with participants randomized to placebo and } \\
\text { experimental vaccine (CvnCoV)) cohorts in healthy adults aged } 18 \text { years } \\
\text { and older.. ClinicalTrials.gov Identifier: } \text { NCT04652102 Estimated } \\
\text { Study Completion Date : March 4, } 2023\end{array}$ \\
\hline $\begin{array}{l}\text { Chinese Academy } \\
\text { of Medical Sciences } \\
16\end{array}$ & Inactivated & 2 & $\begin{array}{l}\text { Day } 0 \\
\text { and } \\
\text { Day } \\
14\end{array}$ & IM & $\begin{array}{l}\text { Brazil, } \\
\text { Malaysia }\end{array}$ & Recruiting & 34020 & $\begin{array}{l}\text { Randomized, double-blind, placebo-controlled clinical trial with } \\
\text { participants randomized (1:1) to placebo and experimental vaccine } \\
\text { (Vero Cell) cohorts in healthy adults aged } 18 \text { years and older. } \\
\text { ClinicalTrials.gov Identifier: }: \text { NCTO4659239 Estimated Study } \\
\text { Completion Date : March } 2022\end{array}$ \\
\hline AstraZeneca ${ }^{17}$ & $\begin{array}{l}\text { Non- } \\
\text { replicating } \\
\text { viral vector }\end{array}$ & 2 & $\begin{array}{l}\text { Day } 0 \\
\text { and } \\
\text { Day } \\
28\end{array}$ & IM & $\begin{array}{l}\text { United } \\
\text { States, } \\
\text { Argentina, } \\
\text { Chile, } \\
\text { Colombia, } \\
\text { Peru, }\end{array}$ & Recruiting & 30000 & $\begin{array}{l}\text { Multicenter, quadruple-blind (participant, caregiver, investigator, } \\
\text { outcome assessor) placebo-controlled clinical trial with randomized } \\
\text { (2:1) participants to placebo and experimental (AZD1222) vaccine } \\
\text { cohorts in healthy adults aged } 18 \text { years old and older. } \\
\text { ClinicalTrials.gov Identifier : NCT04516746 Estimated Study } \\
\text { Completion Date: October 5, } 2022\end{array}$ \\
\hline Medicago 18 & Recombinant & 2 & $\begin{array}{l}\text { Day } 0 \\
\text { and } \\
\text { Day } \\
21\end{array}$ & IM & $\begin{array}{l}\text { United } \\
\text { States, } \\
\text { Canada }\end{array}$ & Recruiting & 30000 & $\begin{array}{l}\text { A phase II/III, randomized, double-blind, placebo-controlled clinical trial } \\
\text { with participants randomized to placebo and experimental vaccine } \\
\text { cohorts in healthy adults aged } 18 \text { years and older.. } \\
\text { ClinicalTrials.gov Identifier: } \mathrm{NCT04636697} \text { Estimated Study } \\
\text { Completion Date : April 30, } 2022\end{array}$ \\
\hline Novavax ${ }^{19}$ & $\begin{array}{l}\text { Recombinant } \\
\text { Spike Protein } \\
\text { Nanoparticle } \\
\text { Vaccine }\end{array}$ & 2 & $\begin{array}{l}\text { Day } 0 \\
\text { and } \\
\text { Day } \\
21\end{array}$ & IM & $\begin{array}{l}\text { United } \\
\text { States, } \\
\text { Mexico, } \\
\text { Puerto Rico }\end{array}$ & Recruiting & 30000 & $\begin{array}{l}\text { Quadruple-blind (participant, care provider, investigator, outcome } \\
\text { assessor), placebo-controlled randomized clinical trial with participants } \\
\text { randomly assigned to placebo and experimental vaccine (NVX- } \\
\text { CoV2373) cohorts in healthy adults aged } 18 \text { years and older. }\end{array}$ \\
\hline
\end{tabular}




\begin{tabular}{|c|c|c|c|c|c|c|c|c|}
\hline $\begin{array}{l}\text { COVID-19 vaccine } \\
\text { developer / } \\
\text { Manufacturer }\end{array}$ & $\begin{array}{l}\text { Type of } \\
\text { vaccine }\end{array}$ & $\begin{array}{l}\text { Number } \\
\text { of doses }\end{array}$ & $\begin{array}{l}\text { Timing } \\
\text { of } \\
\text { doses }\end{array}$ & $\begin{array}{c}\text { Route of } \\
\text { administration }\end{array}$ & Country & $\begin{array}{l}\text { Recruitment } \\
\text { status }\end{array}$ & $\begin{array}{l}\text { Estimated } \\
\text { number of } \\
\text { participants }\end{array}$ & Description of the clinical trial \\
\hline & $\begin{array}{l}\text { (SARS CoV } 2 \\
\text { rS) with } \\
\text { Matrix-M1 } \\
\text { TM Adjuvant }\end{array}$ & & & & & & & $\begin{array}{l}\text { ClinicalTrials.gov Identifier : } \mathrm{NCTO} 4611802 \text { Estimated Study } \\
\text { Completion Date : December, } 2022\end{array}$ \\
\hline $\begin{array}{l}\text { Janssen Vaccines \& } \\
\text { Prevention B.V } 20\end{array}$ & $\begin{array}{l}\text { Non- } \\
\text { replicating } \\
\text { viral vector }\end{array}$ & 2 & $\begin{array}{l}\text { Day } 0 \\
\text { and } \\
\text { Day } \\
56\end{array}$ & IM & $\begin{array}{l}\text { United } \\
\text { States, } \\
\text { Belgium, } \\
\text { Colombia, } \\
\text { France, } \\
\text { Germany, } \\
\text { Philippines, } \\
\text { South } \\
\text { Africa, } \\
\text { Spain, } \\
\text { United } \\
\text { Kingdom }\end{array}$ & Recruiting & 30000 & $\begin{array}{l}\text { Double-blind, placebo-controlled randomized clinical trial with } \\
\text { participants randomly assigned to placebo and experimental vaccine } \\
\text { (Ad26.COV2.S) cohorts in healthy adults aged } 18 \text { years and older. } \\
\text { ClinicalTrials.gov Identifier: } \text { NCTO4614948 Estimated Study } \\
\text { Completion Date : May 11, } 2023\end{array}$ \\
\hline $\begin{array}{l}\text { Anhui Zhifei } \\
\text { Longcom Biologic } \\
\text { Pharmacy Co.,Ltd } \\
21\end{array}$ & Recombinant & 3 & $\begin{array}{l}\text { Day 0, } \\
\text { Day } \\
30 \text { and } \\
\text { Day } \\
60\end{array}$ & IM & China & Recruiting & 29000 & $\begin{array}{l}\text { Quadruple-blind (participant, care provider, investigator, outcome } \\
\text { assessor), placebo-controlled randomized (1:1) clinical trial with } \\
\text { participants randomly assigned to placebo and experimental vaccine } \\
\text { (CHO cell) cohorts in healthy adults aged } 18 \text { years and older. } \\
\text { ClinicalTrials.gov Identifier: } \text { NCTO4646590 Estimated Study } \\
\text { Completion Date : April, } 2022\end{array}$ \\
\hline $\begin{array}{l}\text { Baharat Biotech } \\
\text { international } \\
\text { Limited } 22\end{array}$ & $\begin{array}{l}\text { Whole-virion } \\
\text { inactivated }\end{array}$ & 2 & - & IM & India & Recruiting & 25800 & $\begin{array}{l}\text { Double-blind, placebo-controlled randomized clinical trial with } \\
\text { participants randomly (1:1) assigned to placebo and experimental } \\
\text { vaccine (BBV152) cohorts in healthy adults aged } 18 \text { to } 99 \text { years. } \\
\text { ClinicalTrials.gov Identifier : NCTO4641481 Estimated Study } \\
\text { Completion Date : March 1, } 2022\end{array}$ \\
\hline Novavax 23 & $\begin{array}{l}\text { Recombinant } \\
\text { Spike Protein } \\
\text { Nanoparticle } \\
\text { Vaccine } \\
\text { (SARS CoV } 2 \\
\text { rS with } \\
\text { Matrix-M1 } \\
\text { TM Adjuvant }\end{array}$ & 2 & $\begin{array}{l}\text { Day } 0 \\
\text { and } \\
\text { Day } \\
21\end{array}$ & IM & $\begin{array}{l}\text { United } \\
\text { Kingdom }\end{array}$ & Recruiting & 15000 & $\begin{array}{l}\text { Quadruple-blind (participant, care provider, investigator, outcome } \\
\text { assessor), placebo-controlled randomized clinical trial with participants } \\
\text { randomly assigned to placebo and experimental vaccine (NVX- } \\
\text { CoV2373) cohorts in healthy adults aged } 18 \text { to } 84 \text { years. } \\
\text { ClinicalTrials.gov Identifier: } \text { NCTO4583995 Estimated Study } \\
\text { Completion Date : January, } 2022\end{array}$ \\
\hline $\begin{array}{l}\text { Health Institutes of } \\
\text { Turkey } 24\end{array}$ & Inactivated & 2 & $\begin{array}{l}\text { Day } 0 \\
\text { and } \\
\text { Day } \\
14\end{array}$ & IM & Turkey & Recruiting & 13000 & $\begin{array}{l}\text { Double-blind, placebo-controlled clinical trial with randomized } \\
\text { participants assigned to placebo and experimental vaccine cohorts } \\
\text { (Vero-Cell) in healthy adults aged } 18 \text { to } 59 \text { years old. } \\
\text { ClinicalTrials.gov Identifier : NCT04582344 Estimated Study } \\
\text { Completion Date : April 15, } 2021\end{array}$ \\
\hline $\begin{array}{l}\text { University of } \\
\text { Oxford } 25\end{array}$ & $\begin{array}{l}\text { Non- } \\
\text { replicating } \\
\text { viral vector }\end{array}$ & 1 or 2 & $\begin{array}{l}\text { If } 2 \\
\text { doses, } \\
4-6 \\
\text { weeks } \\
\text { apart }\end{array}$ & IM & $\begin{array}{c}\text { United } \\
\text { Kingdom }\end{array}$ & Recruiting & 12390 & $\begin{array}{l}\text { Phase II /III, single-blind, controlled clinical trial, having } 11 \text { study groups } \\
\text { with participants aged } 18 \text { years and older. Groups will receive the } \\
\text { experimental vaccine (ChAdOx1 nCoV-19) and others the } \\
\text { meningococcal vaccine (MenACWY). ClinicalTrials.gov Identifier: } \\
\text { NCT04400838 Estimated Study Completion Date : September } 2021\end{array}$ \\
\hline
\end{tabular}




\begin{tabular}{|c|c|c|c|c|c|c|c|c|}
\hline $\begin{array}{l}\text { COVID-19 vaccine } \\
\text { developer / } \\
\text { Manufacturer }\end{array}$ & $\begin{array}{l}\text { Type of } \\
\text { vaccine }\end{array}$ & $\begin{array}{l}\text { Number } \\
\text { of doses }\end{array}$ & $\begin{array}{c}\text { Timing } \\
\text { of } \\
\text { doses }\end{array}$ & $\begin{array}{c}\text { Route of } \\
\text { administration }\end{array}$ & Country & $\begin{array}{l}\text { Recruitment } \\
\text { status }\end{array}$ & $\begin{array}{l}\text { Estimated } \\
\text { number of } \\
\text { participants }\end{array}$ & Description of the clinical trial \\
\hline $\begin{array}{l}\text { Institute Butantan } \\
\text { /Sinovac Life } \\
\text { Sciences CO.,Ltd } 26\end{array}$ & Inactivated & 2 & $\begin{array}{l}\text { Day } 0 \\
\text { and } \\
\text { Day } \\
14\end{array}$ & IM & Brazil & Recruiting & 13060 & $\begin{array}{l}\text { Double-blind, placebo-controlled clinical trial with randomized (1:1) } \\
\text { participants assigned to placebo and experimental vaccine cohorts in } \\
\text { healthy adults aged } 18 \text { years and older. For safety and immunogenicity, } \\
\text { participants are categorized in } 2 \text { age groups: adults (18-59 years) and } \\
\text { elderly ( } 60 \text { years and older). ClinicalTrials.gov Identifier: } \\
\text { NCT04456595 Estimated Study Completion Date : September } 2021\end{array}$ \\
\hline $\begin{array}{l}\text { University of } \\
\text { Oxford }{ }^{27}\end{array}$ & $\begin{array}{l}\text { Non- } \\
\text { replicating } \\
\text { viral vector }\end{array}$ & 1 or 2 & $\begin{array}{l}\text { Day } 0 \\
\text { or Day } \\
\text { O and } \\
\text { Day } \\
28-90\end{array}$ & IM & Brazil & Recruiting & 10300 & $\begin{array}{l}\text { Single-blind, controlled clinical trial, with } 2 \text { study groups of healthcare } \\
\text { professionals and adults with high potential for exposure to SARS- } \\
\text { CoV-2, aged } 18 \text { years and older. One group will receive the } \\
\text { experimental vaccine (ChAdOx1 nCoV-19) and the other will receive } \\
\text { the meningococcal vaccine (MenACWY). ClinicalTrials.gov Identifier: } \\
\text { NCT04536051 Estimated Study Completion Date : September } 2021\end{array}$ \\
\hline $\begin{array}{l}\text { University Peruana } \\
\text { Cayetano Heredia } \\
28\end{array}$ & Inactivated & 2 & $\begin{array}{l}\text { Day } 0 \\
\text { and } \\
\text { Day } \\
14\end{array}$ & IM & Peru & Recruiting & 6000 & $\begin{array}{l}\text { Multicenter, double-blind, placebo-controlled clinical trial with } \\
\text { randomized participants assigned to placebo and experimental vaccines } \\
\text { cohorts in healthy adults aged } 18 \text { to } 60 \text { years old. } \\
\text { ClinicalTrials.gov Identifier: } \text { NCT04612972 Estimated Study } \\
\text { Completion Date : September } 2021\end{array}$ \\
\hline $\begin{array}{l}\text { Research Institute } \\
\text { for Biological } \\
\text { Safety Problems } 29\end{array}$ & Inactivated & 2 & $\begin{array}{l}\text { Day } 0 \\
\text { and } \\
\text { Day } \\
21\end{array}$ & IM & Kazakhstan & $\begin{array}{l}\text { Enrolling by } \\
\text { invitation }\end{array}$ & 3000 & $\begin{array}{l}\text { Multicenter, double-blind, placebo-controlled clinical trial with } \\
\text { randomized participants assigned to placebo }(\mathrm{n}=600) \text { and experimental } \\
\text { vaccine cohorts QazCovid-in } \circledast(\mathrm{n}=2400) \text { in healthy adults aged } 18 \\
\text { years old and older. ClinicalTrials.gov Identifier : } \text { NCT04691908 } \\
\text { Estimated Study Completion Date : July 31, } 2021\end{array}$ \\
\hline ModernaTX, Inc 30 & mRNA & 2 & $\begin{array}{l}\text { Day } 0 \\
\text { and } \\
\text { Day } \\
28\end{array}$ & IM & $\begin{array}{l}\text { United } \\
\text { States }\end{array}$ & Recruiting & 3000 & $\begin{array}{l}\text { A phase II/III, quadruple-blind, placebo-controlled clinical trial with } \\
\text { randomized participants assigned to placebo and experimental vaccine } \\
\text { (mRNA-1273) cohorts in healthy adolescents aged } 12 \text { to } 17 \text { years old } \\
\text { ClinicalTrials.gov Identifier: } \text { NCTO4649151 Estimated Study } \\
\text { Completion Date : June 30, } 2022\end{array}$ \\
\hline CureVac AG 31 & mRNA & 2 & $\begin{array}{l}\text { Day } 0 \\
\text { and } \\
\text { Day } \\
28\end{array}$ & IM & Germany & Recruiting & 2520 & $\begin{array}{l}\text { Double-blind, placebo-controlled clinical trial with randomized } \\
\text { participants (1:1) assigned to placebo and experimental vaccine } \\
\text { (CvnCoV) cohorts in healthy adults aged } 18 \text { years old and older. } \\
\text { ClinicalTrials.gov Identifier : NCT04674189 Estimated Study } \\
\text { Completion Date : April 30, } 2022\end{array}$ \\
\hline $\begin{array}{l}\text { Pontifica } \\
\text { Unversidad } \\
\text { Catolica de Chile } 32\end{array}$ & Inactivated & 2 & $\begin{array}{l}\text { Day } 0 \\
\text { and } \\
\text { Day } \\
14\end{array}$ & IM & Chile & Recruiting & 2300 & $\begin{array}{l}\text { Multicenter, double-blind, placebo-controlled clinical trial with } \\
\text { randomized participants (1:1) assigned to placebo and experimental } \\
\text { vaccine cohorts in healthy adults aged } 18 \text { years old and older. } \\
\text { ClinicalTrials.gov Identifier : NCT04651790 Estimated Study } \\
\text { Completion Date : March } 2022\end{array}$ \\
\hline PT Bio Farma ${ }^{33}$ & Inactivated & 2 & $\begin{array}{l}\text { Day } 0 \\
\text { and } \\
\text { Day } \\
14\end{array}$ & IM & Indonesia & Recruiting & 1620 & $\begin{array}{l}\text { Randomized, double-blind, placebo-controlled clinical trial with } \\
\text { participants randomized ( } 1: 1) \text { to placebo and experimental vaccine } \\
\text { cohorts in healthy adults aged } 18 \text { to } 59 \text { years. } \\
\text { ClinicalTrials.gov Identifier: } \text { NCT04508075 Estimated Study } \\
\text { Completion Date : September } 2021\end{array}$ \\
\hline $\begin{array}{l}\text { Sinovac Biotech } \\
\text { Co., Ltd }{ }^{34}\end{array}$ & Inactivated & 2 & $\begin{array}{l}\text { Day } 0 \\
\text { and }\end{array}$ & IM & China & Recruiting & 1040 & $\begin{array}{l}\text { Randomized, double-blind, placebo-controlled clinical trial to evaluate } \\
\text { the non-inferiority of the commercial scale Inactivated SARS-CoV-2 }\end{array}$ \\
\hline
\end{tabular}




\begin{tabular}{|c|c|c|c|c|c|c|c|c|}
\hline $\begin{array}{l}\text { COVID-19 vaccine } \\
\text { developer / } \\
\text { Manufacturer }\end{array}$ & $\begin{array}{l}\text { Type of } \\
\text { vaccine }\end{array}$ & $\begin{array}{l}\text { Number } \\
\text { of doses }\end{array}$ & $\begin{array}{c}\text { Timing } \\
\text { of } \\
\text { doses }\end{array}$ & $\begin{array}{c}\text { Route of } \\
\text { administration }\end{array}$ & Country & $\begin{array}{l}\text { Recruitment } \\
\text { status }\end{array}$ & $\begin{array}{l}\text { Estimated } \\
\text { number of } \\
\text { participants }\end{array}$ & Description of the clinical trial \\
\hline & & & $\begin{array}{l}\text { Day } \\
14\end{array}$ & & & & & $\begin{array}{l}\text { vaccine against that of the pilot scale among healthy adults aged } 26-45 \\
\text { years, and the open-labelled, bridging non-inferiority of the vaccine } \\
\text { induced immunogenicity in healthy elderly (aged } 60 \text { years and older) } \\
\text { against that in healthy adults (18-59 years old). } \\
\text { ClinicalTrials.gov Identifier: } \text { NCT04617483 Estimated Study } \\
\text { Completion Date: May 31, } 2021\end{array}$ \\
\hline AnGes, INC 35 & DNA & 2 & $\begin{array}{l}\text { Day } 0 \\
\text { and } \\
\text { Day } \\
14 \text { or } \\
\text { Day } 0 \\
\text { and } \\
\text { Day } \\
28\end{array}$ & IM & Japan & Recruiting & 500 & $\begin{array}{l}\text { A phase II/III, randomized, double-blind, placebo-controlled clinical to } \\
\text { assess safety, immunogenicity, and efficacy of twice dosing of IM } \\
\text { AG0302-Covid-19 (2mg) in healthy adults aged } 18 \text { years and older. } \\
\text { ClinicalTrials.gov Identifier : NCTO4655625 Estimated Study } \\
\text { Completion Date : March } 31,2022\end{array}$ \\
\hline $\begin{array}{l}\text { Clover } \\
\text { Biopharmaceuticals } \\
\text { AUS Pty Ltd }{ }^{36}\end{array}$ & $\begin{array}{l}\text { Adjuvanted } \\
\text { recombinant } \\
\text { Subunit } \\
\text { vaccine }\end{array}$ & 2 & $\begin{array}{l}\text { Day } 0 \\
\text { and } \\
\text { Day } \\
21\end{array}$ & IM & $\begin{array}{l}\text { Belgium, } \\
\text { Brazil, } \\
\text { Colombia, } \\
\text { Dominican } \\
\text { Republic, } \\
\text { Germany, } \\
\text { Nepal, } \\
\text { Panama, } \\
\text { Philippines, } \\
\text { Poland, } \\
\text { South Africa }\end{array}$ & $\begin{array}{c}\text { Not yet } \\
\text { recruiting }\end{array}$ & 34000 & $\begin{array}{l}\text { A Phase II/III, double-blind, placebo-controlled clinical trial with } \\
\text { randomized participants to placebo and experimental vaccine } \\
\text { (ASO3-adjuvanted SCB-2019) cohorts in healthy adults aged } 18 \text { years } \\
\text { old and older. ClinicalTrials.gov Identifier : NCT04672395 Estimated } \\
\text { Study Completion Date : March, } 2022\end{array}$ \\
\hline COVAXX ${ }^{37}$ & $\begin{array}{l}\text { Protein } \\
\text { subunit }\end{array}$ & 2 & $\begin{array}{l}\text { Day } 0 \\
\text { and } \\
\text { Day } \\
28\end{array}$ & IM & - & $\begin{array}{c}\text { Not yet } \\
\text { Recruiting }\end{array}$ & 7320 & $\begin{array}{l}\text { A phase II/III, multicenter, double-blind, placebo-controlled, dose- } \\
\text { response study to evaluate the safety, immunogenicity and efficacity of } \\
\text { UB-612 in age groups, adults aged } 18 \text { to } 59 \text { years and elderly aged more } \\
\text { than } 60 \text { years with or without comorbidities. } \\
\text { ClinicalTrials.gov Identifier: }: \text { NCT04683224 Estimated Study } \\
\text { Completion Date : March 22, } 2023\end{array}$ \\
\hline $\begin{array}{l}\text { Gamaleya Research } \\
\text { Institute of } \\
\text { Epidemiology and } \\
\text { Microbiology, } \\
\text { Health Ministry of } \\
\text { the Russian } \\
\text { Federation } \\
\text { 38 }\end{array}$ & $\begin{array}{l}\text { Combined } \\
\text { viral vector } \\
\text { (Adenovirus } \\
\text { (rAd26-S+ } \\
\text { rAd5-S)) }\end{array}$ & 2 & $\begin{array}{l}\text { Day } 0 \\
\text { and } \\
\text { Day } \\
21\end{array}$ & IM & Venezuela & $\begin{array}{c}\text { Not yet } \\
\text { Recruiting }\end{array}$ & 2000 & $\begin{array}{l}\text { Double-blind, placebo-controlled clinical trial with participants } \\
\text { randomly assigned }(3: 1) \text { to placebo }(n=500) \text { and experimental (GAM- } \\
\text { COVID-Vac; } n=1500) \text { vaccine cohorts in healthy adults aged } 18 \text { years } \\
\text { and older. ClinicalTrials.gov Identifier }: \text { NCTO4642339 Estimated } \\
\text { Study Completion Date : December, } 2021\end{array}$ \\
\hline $\begin{array}{l}\text { Dr Reddy's } \\
\text { Laboratories } \\
\text { Limited / Gamaleya } \\
\text { Research Institute } \\
\text { of Epidemiology } \\
\text { and Microbiology, } \\
\text { Health Ministry of }\end{array}$ & $\begin{array}{l}\text { Combined } \\
\text { viral vector }\end{array}$ & 2 & $\begin{array}{l}\text { Day } 0 \\
\text { and } \\
\text { Day } \\
21\end{array}$ & IM & India & $\begin{array}{c}\text { Not yet } \\
\text { Recruiting }\end{array}$ & 1600 & $\begin{array}{l}\text { A phase II/III, double-blind, placebo-controlled clinical trial with } \\
\text { participants randomly assigned (3:1) to experimental (GAM-COVID- } \\
\text { Vac) vaccine and placebo cohorts in healthy adults aged } 18 \text { years and } \\
\text { older. ClinicalTrials.gov Identifier : } \text { NCT04640233 Estimated Study } \\
\text { Completion Date : September, } 2021\end{array}$ \\
\hline
\end{tabular}




\begin{tabular}{|c|c|c|c|c|c|c|c|c|}
\hline $\begin{array}{l}\text { COVID-19 vaccine } \\
\text { developer/ } \\
\text { Manufacturer }\end{array}$ & $\begin{array}{l}\text { Type of } \\
\text { vaccine }\end{array}$ & $\begin{array}{l}\text { Number } \\
\text { of doses }\end{array}$ & $\begin{array}{l}\text { Timing } \\
\text { of } \\
\text { doses }\end{array}$ & $\begin{array}{c}\text { Route of } \\
\text { administration }\end{array}$ & Country & $\begin{array}{l}\text { Recruitment } \\
\text { status }\end{array}$ & $\begin{array}{c}\text { Estimated } \\
\text { number of } \\
\text { participants }\end{array}$ & Description of the clinical trial \\
\hline \multicolumn{9}{|l|}{$\begin{array}{l}\text { the Russian } \\
\text { Federation } 39\end{array}$} \\
\hline $\begin{array}{l}\text { Pfizer/BioNTech SE } \\
40\end{array}$ & RNA & 2 & $\begin{array}{l}\text { Day } 0 \\
\text { and } \\
\text { Day } \\
21\end{array}$ & IM & - & $\begin{array}{c}\text { Not yet } \\
\text { Recruiting }\end{array}$ & 1280 & $\begin{array}{l}\text { Double-blind, placebo-controlled clinical trial with participants } \\
\text { randomly assigned to placebo and experimental vaccine (BNT162B2) } \\
\text { cohorts in healthy adults aged } 18 \text { to } 55 \text { years. } \\
\text { ClinicalTrials.gov Identifier: NCT04713553 Estimated Study } \\
\text { Completion Date : April 9, } 2021\end{array}$ \\
\hline $\begin{array}{l}\text { Gamaleya Research } \\
\text { Institute of } \\
\text { Epidemiology and } \\
\text { Microbiology, } \\
\text { Health Ministry of } \\
\text { the Russian } \\
\text { Federation } \\
41\end{array}$ & $\begin{array}{l}\text { Combined } \\
\text { viral vector }\end{array}$ & 1 & Day 0 & IM & $\begin{array}{c}\text { United Arab } \\
\text { Emirates }\end{array}$ & $\begin{array}{l}\text { Not yet } \\
\text { Recruiting }\end{array}$ & 1000 & $\begin{array}{l}\text { Double-blind, placebo-controlled clinical trial with participants } \\
\text { randomly assigned (3:1) to placebo }(\mathrm{n}=250) \text { and experimental (GAM- } \\
\text { COVID-Vac; } \mathrm{n}=750) \text { vaccine cohorts in healthy adults aged } 18 \text { years } \\
\text { and older. The trial subjects will be randomized into five age strata: } \\
18-30,31-40,41-50,51-60 \text {, and } 60+\text { years ClinicalTrials.gov Identifier } \\
\text { : NCT04656613 Estimated Study Completion Date : December, } 2021\end{array}$ \\
\hline AstraZeneca 42 & $\begin{array}{l}\text { Non- } \\
\text { replicating } \\
\text { viral vector }\end{array}$ & 2 & $\begin{array}{l}\text { Day } 0 \\
\text { and } \\
\text { Day } \\
28\end{array}$ & IM & $\begin{array}{l}\text { Russian } \\
\text { Federation }\end{array}$ & Suspended & 100 & $\begin{array}{l}\text { Multicenter, unblinded, uncontrolled clinical trial in which all } \\
\text { participants receive the experimental vaccine (AZD1222). Included are } \\
\text { healthy adults aged } 18 \text { years and older. ClinicalTrials.gov Identifier: } \\
\text { NCT04540393 Estimated Study Completion Date : Mach 12, } 2021\end{array}$ \\
\hline
\end{tabular}

"IM : Intramuscular 


\section{OTHER VACCINES TO FIGHT COVID-19}

\section{MEASLES VACCINE}

With the hypothesis that the measles vaccine could reduce the incidence of COVID-19, as of January 24, 2021, there were three clinical trials, in phase III, using this vaccine in the fight against infection with SARS-CoV-2:

- An international clinical trial (NCT04333732), randomized, double-blind, placebo-controlled, in healthcare workers at risk of contracting COVID-19 $(\mathrm{N}=30000)$ and aged 18 years and older. These are randomly assigned to cohorts of placebo vaccine and MMR or MR vaccine. The estimated end of study date is August 2021. ${ }^{43}$

- A randomized, single-blinded, placebo-controlled clinical trial in New Orleans (NCT04475081), recruiting healthy healthcare workers $(\mathrm{N}=60)$ aged 18 to 70 years. They are randomly assigned to cohorts of placebo vaccine and MMR vaccine. The estimated end of study date is December $1^{\text {st }}, 2021 .^{44}$

- A randomized clinical trial in Egypt (NCT04357028), single-blind, placebo-controlled, recruiting healthy healthcare workers $(\mathrm{N}=200)$ and aged between 18 and 50 years. Participants are randomly assigned to cohorts of placebo vaccine and MMR vaccine. The estimated end of study date was November $1^{\text {st }}, 2020$, but the clinical trial was suspended due to failure of subject recruitment. ${ }^{45}$

POLIO VACCINE

Both polio and coronavirus are positive strand RNA viruses, it is likely that they can induce common innate immune mechanisms. There were three clinical trials:

- A randomized clinical trial in Guinea-Bissau (NCT04445428), double-blind and in phase IV, evaluating the effect of the administration of the oral polio vaccine (OPV) compared to the absence of vaccine in 3400 people, aged over 50 years and recruited by invitation. The objective of the trial is to test the hypothesis that OPV reduces the combined risk of admission or death from morbidity by at least $28 \%$ over the next six months. The estimated end of this study date is December $2021 .{ }^{46}$

- A Phase IV clinical trial in United States (NCT04639375), evaluating whether an immune response to SARS-CoV $2 \mathrm{RdRp}$ is induced in adults after receiving a booster inoculation of IPV. The number of participants is estimated at 25 healthy volunteers aged between 18 and 80 years old. All participants will receive one IPV by injection. The estimated end of this study date is January 15, 2021. ${ }^{47}$

- A randomized, multi-center, phase III, clinical trial in the United States and New Zealand (NCT04540185), evaluating the safety and efficacy of OPV with and without NA-831 versus to placebo. The number of participants is estimated at 3600 , aged over 18 years, in good health and recruited by invitation. ${ }^{48}$

BCG VACCINE

Hypotheses have been made that the tuberculosis vaccine (BCG) may induce partial protection against the severity of infection with SARS-CoV-2. In this context, as of January 24 , 2021, there were 23 clinical trials using the BCG vaccine, including six in phase IV. ${ }^{49-54}$ Four (17\%) clinical trials were active and not recruiting, ${ }^{49,55-57}$ while the Colombian clinical trial was withdrawn due to the lack of sponsorship. ${ }^{58}$ The number of recruits ranged from 59 to 10078 (Table 2).

PUBLISHED CLINICAL TRIALS’ RESULTS

As of January 24, 2021, there was 13 clinical trials' published results in different phases, of which six were in phase I/II ${ }^{59-64}$ and four had a number of participants less than $100.60,64-66$ Only two clinical trials had a non-randomized trial. ${ }^{60,67}$ All studies concerned healthy adults aged 18 years and over. In general, local and systemic reactions if present, were described as mild to moderate and consisted in injection site pain, fever, myalgia, headache and fatigue (Table 3).

At this time, there is no determination as to whether a vaccine candidate will be universal or indicated for specific populations, or how many doses will be needed, or the likely presentations. ${ }^{68}$ 
Table 2: Phase III and IV clinical trials using the tuberculosis vaccine for the fight against COVID-19 as of January 24, 2021

\begin{tabular}{|c|c|c|c|c|c|c|c|c|}
\hline $\begin{array}{l}\text { COVID-19 } \\
\text { vaccine } \\
\text { developer/ } \\
\text { Manufacturer }\end{array}$ & $\begin{array}{c}\text { Clinical } \\
\text { Trial } \\
\text { phase }\end{array}$ & $\begin{array}{c}\text { Number } \\
\text { of } \\
\text { Doses }\end{array}$ & $\begin{array}{l}\text { Timing } \\
\text { of } \\
\text { doses }\end{array}$ & $\begin{array}{c}\text { Route of } \\
\text { administration }\end{array}$ & Country & $\begin{array}{l}\text { Recruitment } \\
\text { Status }\end{array}$ & $\begin{array}{l}\text { Estimated } \\
\text { number of } \\
\text { participants }\end{array}$ & Description of the clinical trial \\
\hline $\begin{array}{l}\text { Radboud } \\
\text { University } 49\end{array}$ & $\begin{array}{l}\text { Phase } \\
\text { IV }\end{array}$ & 1 & Day 0 & ID & Netherlands & $\begin{array}{l}\text { Active, not } \\
\text { recruiting }\end{array}$ & 2014 & $\begin{array}{l}\text { A randomized, multicenter, single-blind, placebo-controlled clinical trial with } \\
\text { participants randomly assigned (1:1) to one BCG vaccine cohort and another } \\
\text { placebo cohort in healthy subjects aged } 60 \text { years and older. } \\
\text { ClinicalTrials.gov Identifier : } \underline{\text { NCTO } 04417335} \text { Estimated Study Completion Date : } \\
\text { May } 2021\end{array}$ \\
\hline $\begin{array}{l}\text { UMC Utrecht } \\
50\end{array}$ & $\begin{array}{l}\text { Phase } \\
\text { IV }\end{array}$ & 1 & Day 0 & ID & Netherlands & Recruiting & 5200 & $\begin{array}{l}\text { Randomized, multicenter, quadruple-blind (participant, care provider, investigator, } \\
\text { outcome assessor) placebo-controlled clinical trial with participants randomized } \\
\text { (1:1) to one BCG vaccine cohort and another placebo cohort in subjects aged } 60 \\
\text { years and older, with a medical history. ClinicalTrials.gov Identifier: } \\
\text { NCT04537663 Estimated Study Completion Date : April } 2021\end{array}$ \\
\hline $\begin{array}{l}\text { Texas A\&M } \\
\text { University } 51\end{array}$ & $\begin{array}{l}\text { Phase } \\
\text { IV }\end{array}$ & 1 & Day 0 & ID & $\begin{array}{l}\text { United } \\
\text { States }\end{array}$ & Recruiting & 1800 & $\begin{array}{l}\text { Randomized, multicenter, double-blind, placebo-controlled clinical trial with } \\
\text { participants randomly assigned (1:1) to a BCG vaccine cohort and an another } \\
\text { placebo cohort in high risk healthy healthcare workers with direct COVID-19 } \\
\text { infected patients contacts and aged between } 18 \text { and } 75 \text { years. } \\
\text { ClinicalTrials.gov Identifier : NCT04348370 Estimated Study Completion Date: } \\
\text { November } 2021\end{array}$ \\
\hline $\begin{array}{l}\text { University of } \\
\text { Southern } \\
\text { Denmark } 52\end{array}$ & $\begin{array}{l}\text { Phase } \\
\text { IV }\end{array}$ & 1 & Day 0 & ID & $\begin{array}{l}\text { Cape Verde, } \\
\text { Guinea- } \\
\text { Bissau, } \\
\text { Mozambique }\end{array}$ & Recruiting & 1050 & $\begin{array}{l}\text { Randomized, multicenter, double-blind, placebo-controlled clinical trial with } \\
\text { participants randomly }(1: 1) \text { assigned to a BCG vaccine cohort and another placebo } \\
\text { cohort in healthy healthcare workers aged } 18 \text { years and older. } \\
\text { ClinicalTrials.gov Identifier : NCT04641858 Estimated Study Completion Date : } \\
\text { March } 2022\end{array}$ \\
\hline $\begin{array}{l}\text { University of } \\
\text { Campinas, } \\
\text { Brazil } 53\end{array}$ & $\begin{array}{l}\text { Phase } \\
\text { IV }\end{array}$ & 1 & Day 0 & ID & Brazil & Recruiting & 1000 & $\begin{array}{l}\text { Randomized, multicenter, double-blind, placebo-controlled clinical trial with } \\
\text { participants randomly assigned (1:1) to one BCG vaccine cohort and another } \\
\text { placebo cohort in COVID-19 positive subjects aged } 18 \text { years and older. } \\
\text { ClinicalTrials.gov Identifier : NCT04369794 Estimated Study Completion Date : } \\
\text { August } 2023\end{array}$ \\
\hline $\begin{array}{l}\text { Hellenic } \\
\text { Institute for } \\
\text { the Study of } \\
\text { Sepsis } 54 / t d>\end{array}$ & $\begin{array}{l}\text { Phase } \\
\text { IV }\end{array}$ & 1 & Day 0 & ID & Greece & Recruiting & 900 & $\begin{array}{l}\text { Quadruple-blind randomized clinical trial (participant, care provider, investigator, } \\
\text { outcome assessor) placebo-controlled with healthy participants aged } 50 \text { years and } \\
\text { older and randomly assigned (1:1) to one BCG vaccine cohort and another placebo } \\
\text { cohort. ClinicalTrials.gov Identifier: NCT04414267 Estimated Study Completion } \\
\text { Date : May 25, } 2021\end{array}$ \\
\hline $\begin{array}{l}\text { UMC } \\
\text { Utrecht/ } \\
\text { Radboud } \\
\text { University } 55\end{array}$ & $\begin{array}{c}\text { Phase } \\
\text { III }\end{array}$ & 1 & Day 0 & ID & Netherlands & $\begin{array}{l}\text { Active, not } \\
\text { recruiting }\end{array}$ & 1500 & $\begin{array}{l}\text { Placebo-controlled, randomized, quadruple-blind (participant, provider, } \\
\text { investigator, outcome assessor) clinical trial with participants randomly (1:1) } \\
\text { assigned to a BCG vaccine cohort and a placebo cohort among healthy healthcare } \\
\text { workers in hospitals, aged } 18 \text { years and older, and caring for COVID-19 positive } \\
\text { patients. ClinicalTrials.gov Identifier : NCTO4328441 Estimated Study Completion } \\
\text { Date : April 30, } 2021\end{array}$ \\
\hline $\begin{array}{l}\text { Hospital } \\
\text { University Dr. } \\
\text { Jose E. } \\
\text { Gonzalez } 56\end{array}$ & $\begin{array}{c}\text { Phase } \\
\text { III }\end{array}$ & 1 & Day 0 & ID & Mexico & $\begin{array}{l}\text { Active, not } \\
\text { recruiting }\end{array}$ & 908 & $\begin{array}{l}\text { Multicenter, randomized, triple-blind, placebo-controlled clinical trial with } \\
\text { participants randomly assigned (1:1) to one BCG vaccine cohort and another } \\
\text { placebo cohort in healthcare workers aged } 18 \text { years and older. } \\
\text { ClinicalTrials.gov Identifier : NCT04461379 Estimated Study Completion Date : } \\
\text { January 1, } 2021\end{array}$ \\
\hline
\end{tabular}




\begin{tabular}{|c|c|c|c|c|c|c|c|c|}
\hline $\begin{array}{l}\text { COVID-19 } \\
\text { vaccine } \\
\text { developer / } \\
\text { Manufacturer }\end{array}$ & $\begin{array}{c}\text { Clinical } \\
\text { Trial } \\
\text { phase }\end{array}$ & $\begin{array}{l}\text { Number } \\
\text { of } \\
\text { Doses }\end{array}$ & $\begin{array}{c}\text { Timing } \\
\text { of } \\
\text { doses }\end{array}$ & $\begin{array}{c}\text { Route of } \\
\text { administration }\end{array}$ & Country & $\begin{array}{l}\text { Recruitment } \\
\text { Status }\end{array}$ & $\begin{array}{c}\text { Estimated } \\
\text { number of } \\
\text { participants }\end{array}$ & Description of the clinical trial \\
\hline $\begin{array}{l}\text { Vakzine } \\
\text { Projekt } \\
\text { Management } \\
\text { GmbH } 57\end{array}$ & $\begin{array}{l}\text { Phase } \\
\text { III }\end{array}$ & 1 & Day 0 & ID & Germany & $\begin{array}{l}\text { Active not } \\
\text { recruiting }\end{array}$ & 59 & $\begin{array}{l}\text { Randomized, triple-blind, placebo-controlled clinical trial with participants } \\
\text { randomly assigned (1:1) to one BCG vaccine (VPM1002) cohort and an another } \\
\text { placebo cohort in hospital workers with high exposure to SARS-CoV-2, healthy and } \\
\text { aged } 18 \text { years old and older. ClinicalTrials.gov Identifier: NCTO4387409 Estimated } \\
\text { Study Completion Date : May 1, } 2021\end{array}$ \\
\hline $\begin{array}{l}\text { Murdoch } \\
\text { Children's } \\
\text { Research } \\
\text { Institute } 69\end{array}$ & $\begin{array}{l}\text { Phase } \\
\text { III }\end{array}$ & 1 & Day 0 & ID & $\begin{array}{l}\text { Australia, } \\
\text { Netherland, } \\
\text { Spain, } \\
\text { United } \\
\text { Kingdom }\end{array}$ & Recruiting & 10078 & $\begin{array}{l}\text { Randomized, multicenter, double-blind, placebo-controlled clinical trial with } \\
\text { participants randomly assigned to a BCG vaccine cohort and another placebo } \\
\text { cohort in healthy healthcare workers aged } 18 \text { years and older. } \\
\text { ClinicalTrials.gov Identifier : NCT04327206 Estimated Study Completion Date : } \\
\text { March 30, } 2022\end{array}$ \\
\hline $\begin{array}{l}\text { University } \\
\text { Health } \\
\text { Network, } \\
\text { Toronto } 70\end{array}$ & $\begin{array}{l}\text { Phase } \\
\text { III }\end{array}$ & 1 & Day 0 & ID & Canada & Recruiting & 3626 & $\begin{array}{l}\text { Randomized, double-blind, placebo-controlled clinical trial with participants } \\
\text { randomly assigned to a BCG vaccine (VPM1002) cohort and another placebo } \\
\text { cohort among frontline employees (municipal or provincial police, emergency } \\
\text { medical services, fire departments, public transport service, health service, food } \\
\text { manufacturing facility) aged } 18 \text { years and over. Clinical Trials.gov Identifier : } \\
\text { NCT04439045 Estimated Study Completion Date : July 1, } 2021\end{array}$ \\
\hline $\begin{array}{l}\text { Tuberculosis } \\
\text { Research } \\
\text { Center, India } \\
71\end{array}$ & $\begin{array}{l}\text { Phase } \\
\text { III }\end{array}$ & 1 & Day 0 & ID & India & Recruiting & 2175 & $\begin{array}{l}\text { Non-randomized, unblinded clinical trial with healthy participants aged between } 60 \\
\text { and } 80 \text { years, assigned (2:1) to one BCG vaccine cohort and one without } \\
\text { vaccination. ClinicalTrials.gov Identifier: } \text { NCT04475302 Estimated Study } \\
\text { Completion Date : May } 2021\end{array}$ \\
\hline $\begin{array}{l}\text { Vakzine } \\
\text { Projekt } \\
\text { Management } \\
\text { GmbH }^{72}\end{array}$ & $\begin{array}{l}\text { Phase } \\
\text { III }\end{array}$ & 1 & Day 0 & ID & Germany & Recruiting & 2038 & $\begin{array}{l}\text { Randomized, multicenter, triple-blind, placebo-controlled clinical trial with } \\
\text { participants randomly assigned (1:1) to one BCG vaccine cohort (VPM1002) and } \\
\text { another placebo cohort in healthy adults aged } 60 \text { years and older. } \\
\text { ClinicalTrials.gov Identifier : NCT04435379 Estimated Study Completion Date : } \\
\text { September 30, } 2021\end{array}$ \\
\hline $\begin{array}{l}\text { Bandim } \\
\text { Health } \\
\text { Project }\end{array}$ & $\begin{array}{l}\text { Phase } \\
\text { III }\end{array}$ & 1 & Day 0 & ID & Denmark & Recruiting & 1900 & $\begin{array}{l}\text { Randomized, double-blind, placebo-controlled clinical trial with participants } \\
\text { randomly assigned (1:1) to one BCG vaccine cohort and an another placebo cohort } \\
\text { in healthy adults aged } 65 \text { years and older. ClinicalTrials.gov Identifier : } \\
\text { NCT04542330 Estimated Study Completion Date : March } 2022\end{array}$ \\
\hline $\begin{array}{l}\text { Bandim } \\
\text { Health } \\
\text { Project }\end{array}$ & $\begin{array}{l}\text { Phase } \\
\text { III }\end{array}$ & 1 & Day 0 & ID & Denmark & Recruiting & 1500 & $\begin{array}{l}\text { Randomized, double-blind, placebo-controlled clinical trial with participants } \\
\text { randomly assigned (1:1) to a BCG vaccine cohort and a placebo cohort in healthy } \\
\text { healthcare workers with direct contact with patients with COVID-19 and aged } 18 \\
\text { years to } 100 \text { years. ClinicalTrials.gov Identifier : NCTO4373291 Estimated Study } \\
\text { Completion Date : August, } 2021\end{array}$ \\
\hline $\begin{array}{l}\text { Assistance } \\
\text { Publique- } \\
\text { Hôpitaux de } \\
\text { Paris } 75\end{array}$ & $\begin{array}{l}\text { Phase } \\
\text { III }\end{array}$ & 1 & Day 0 & ID & France & Recruiting & 1120 & $\begin{array}{l}\text { Randomized, single-blind, placebo-controlled clinical trial with participants } \\
\text { randomly assigned (1:1) to one BCG vaccine cohort and another placebo cohort in } \\
\text { healthy healthcare workers treating patients with COVID-19 and aged } 18 \text { years and } \\
\text { older. ClinicalTrials.gov Identifier : NCT04384549 Estimated Study Completion } \\
\text { Date : February 20, } 2021\end{array}$ \\
\hline $\begin{array}{l}\text { Hanna } \\
\text { Czajka, } \\
\text { University of } \\
\text { Rzeszow } 76\end{array}$ & $\begin{array}{l}\text { Phase } \\
\text { III }\end{array}$ & 1 & Day 0 & ID & Poland & Recruiting & 1000 & $\begin{array}{l}\text { Multicenter, placebo-controlled, randomized, Partially double blinded clinical trial } \\
\text { with participants randomly assigned (1:1) to one BCG vaccine cohort and another } \\
\text { placebo cohort among healthy health care workers aged } 25 \text { years and older. } \\
\text { ClinicalTrials.gov Identifier : } \mathrm{NCT} 04648800 \text { Estimated Study Completion Date : }\end{array}$ \\
\hline
\end{tabular}




\begin{tabular}{|c|c|c|c|c|c|c|c|c|}
\hline $\begin{array}{l}\text { COVID-19 } \\
\text { vaccine } \\
\text { developer/ } \\
\text { Manufacturer }\end{array}$ & $\begin{array}{c}\text { Clinical } \\
\text { Trial } \\
\text { phase }\end{array}$ & $\begin{array}{l}\text { Number } \\
\text { of } \\
\text { Doses }\end{array}$ & $\begin{array}{l}\text { Timing } \\
\text { of } \\
\text { doses }\end{array}$ & $\begin{array}{c}\text { Route of } \\
\text { administration }\end{array}$ & Country & $\begin{array}{l}\text { Recruitment } \\
\text { Status }\end{array}$ & $\begin{array}{l}\text { Estimated } \\
\text { number of } \\
\text { participants }\end{array}$ & Description of the clinical trial \\
\hline & & & & & & & & April , 2021 \\
\hline $\begin{array}{l}\text { Henry M. } \\
\text { Jackson } \\
\text { Foundation } \\
\text { for the } \\
\text { advancement } \\
\text { of Military } \\
\text { Medicine }\end{array}$ & $\begin{array}{l}\text { Phase } \\
\text { III }\end{array}$ & 1 & Day 0 & ID & $\begin{array}{l}\text { United } \\
\text { States }\end{array}$ & Recruiting & 550 & $\begin{array}{l}\text { Multicenter, placebo-controlled, randomized, triple-blind (participant, care } \\
\text { provider, investigator) clinical trial with participants randomly assigned (1:1) to one } \\
\text { BCG vaccine cohort (Tice } ® \text { BCG) and another placebo cohort among healthy } \\
\text { healthcare workers who are likely to care for Covid-19 patients and aged } 18 \text { to } 64 \\
\text { years old. ClinicalTrials.gov Identifier : NCT04632537 Estimated Study } \\
\text { Completion Date : April, } 2023\end{array}$ \\
\hline $\begin{array}{l}\text { TASK Applied } \\
\text { Science } 78\end{array}$ & $\begin{array}{l}\text { Phase } \\
\text { III }\end{array}$ & 1 & Day 0 & ID & South Africa & Recruiting & 500 & $\begin{array}{l}\text { Placebo-controlled, randomized, quadruple-blind (participant, provider, } \\
\text { investigator, outcome assessor) clinical trial with participants randomly assigned } \\
\text { (1:1) to one BCG vaccine cohort and another placebo cohort among healthy } \\
\text { healthcare workers aged } 18 \text { years and older. ClinicalTrials.gov Identifier : } \\
\text { NCT04379336 Estimated Study Completion Date :April 28, } 2021\end{array}$ \\
\hline $\begin{array}{l}\text { Fundació } \\
\text { Institute } \\
\text { Germans } \\
\text { Trias i Pujol } \\
79\end{array}$ & $\begin{array}{l}\text { Phase } \\
\text { III }\end{array}$ & 2 & $\begin{array}{l}\text { Day } 0 \\
\text { and } \\
\text { Day } \\
14\end{array}$ & ID & Spain & $\begin{array}{l}\text { Not yet } \\
\text { recruiting }\end{array}$ & 315 & $\begin{array}{l}\text { Quadruple-blind randomized clinical trial (participant, provider, investigator, } \\
\text { outcome assessor) placebo-controlled trial with participants randomly assigned to } \\
\text { cohorts of placebo vaccine and RUTI@ vaccine in healthy healthcare workers aged } \\
18 \text { years old and older. ClinicalTrials.gov Identifier : NCT04453488 Estimated } \\
\text { Study Completion Date : December } 2020\end{array}$ \\
\hline $\begin{array}{l}\text { Harvard } \\
\text { Medical } \\
\text { School } 80\end{array}$ & $\begin{array}{l}\text { Phase } \\
\text { III }\end{array}$ & 1 & Day 0 & ID & - & $\begin{array}{l}\text { Not yet } \\
\text { recruiting }\end{array}$ & 2100 & $\begin{array}{l}\text { Randomized, triple-blind, placebo-controlled clinical trial with participants } \\
\text { randomly assigned (1:1) to BCG vaccine and placebo cohorts in healthy subjects } \\
\text { aged } 70 \text { years and older and resident in a long-term care facilities. } \\
\text { ClinicalTrials.gov Identifier : NCT04534803 Estimated Study Completion Date: } \\
\text { November } 30,2021\end{array}$ \\
\hline $\begin{array}{l}\text { Ain Shams } \\
\text { University } 81\end{array}$ & $\begin{array}{l}\text { Phase } \\
\text { III }\end{array}$ & 1 & Day 0 & ID & Egypt & $\begin{array}{l}\text { Not yet } \\
\text { recruiting }\end{array}$ & 900 & $\begin{array}{l}\text { Multi-center, randomized, single-blind clinical trial with participants randomly } \\
\text { assigned (2: } 1) \text { to a BCG vaccine cohort }(n=600) \text { and a placebo cohort }(n=300) \text { in } \\
\text { healthy healthcare workers working in the isolation hospitals for COVID-19 cases } \\
\text { and aged } 18 \text { years and older. ClinicalTrials.gov Identifier : NCTO4350931 } \\
\text { Estimated Study Completion Date : December } 1,2020\end{array}$ \\
\hline $\begin{array}{l}\text { University of } \\
\text { Antioquia } 58\end{array}$ & $\begin{array}{l}\text { Phase } \\
\text { III }\end{array}$ & 1 & Day 0 & ID & Colombia & $\begin{array}{l}\text { Withdrawn } \\
\text { (Principal } \\
\text { Investigator } \\
\text { did not } \\
\text { obtain } \\
\text { sponsorship } \\
\text { to carry it } \\
\quad \text { out) }\end{array}$ & - & $\begin{array}{l}\text { Randomized, multicenter, double-blind, placebo-controlled clinical trial with } \\
\text { participants randomized (1:1) to BCG vaccine and placebo cohorts in healthy adults } \\
\text { aged } 18 \text { to } 65 \text { years. ClinicalTrials.gov Identifier : NCT04362124 Estimated Study } \\
\text { Completion Date: November } 2021\end{array}$ \\
\hline
\end{tabular}

* ID : Intradermal 
Table 3: COVID-19 vaccine clinical trials published results, as of January 24, 2021

\begin{tabular}{|c|c|c|c|c|c|c|c|c|c|}
\hline $\begin{array}{l}\text { COVID-19 } \\
\text { vaccine } \\
\text { developer/ } \\
\text { Manufacturer }\end{array}$ & Identifier & Phase & $\begin{array}{l}\text { Brief } \\
\text { description }\end{array}$ & Vaccine & Country & $\begin{array}{l}\text { Number of } \\
\text { participants }\end{array}$ & Published Results & $\begin{array}{l}\text { Status of the } \\
\text { vaccine }\end{array}$ & References \\
\hline $\begin{array}{l}\text { CanSino } \\
\text { Biologics Inc. }\end{array}$ & NCT04313127 & 1 & $\begin{array}{l}\text { A non- } \\
\text { randomized } \\
\text { clinical trial, in } \\
\text { healthy adults } \\
\text { (18-60 years) }\end{array}$ & $\begin{array}{l}\text { Recombinant } \\
\text { adenovirus } \\
\text { type } 5 \text { vector }\end{array}$ & $\begin{array}{l}\text { Wuhan, } \\
\text { China }\end{array}$ & 108 & $\begin{array}{l}\text { The vaccine was tolerable, immunogenic } \\
28 \text { days after vaccination and that rapid } \\
\text { specific T lymphocytes were noted from } \\
\text { day } 14 \text { post vaccination. Most adverse } \\
\text { reactions were mild or moderate in } \\
\text { severity. The most common were pain In } \\
\text { injection side (54\%), fever (46\%), fatigue } \\
(44 \%) \text {, headache (39\%) and muscle pain } \\
(17 \%) \text {. }\end{array}$ & $\begin{array}{l}\text { Registered in } \\
\text { phase III } \\
\text { (NCT04526990) }^{14} \\
\text { and recruiting } \\
\text { participants }\end{array}$ & Zhu et al 67 \\
\hline $\begin{array}{l}\text { Institute of } \\
\text { Biotechnology, } \\
\text { Academy of } \\
\text { Military } \\
\text { Medical } \\
\text { Sciences, PLA } \\
\text { of China }\end{array}$ & NCT04341389 & II & $\begin{array}{l}\text { Randomized, } \\
\text { placebo } \\
\text { controlled } \\
\text { clinical trial in } \\
\text { healthy adults } \\
\text { aged } 18 \text { years } \\
\text { and older }\end{array}$ & $\begin{array}{l}\text { Recombinant } \\
\text { adenovirus } \\
\text { type } 5 \text { vector }\end{array}$ & $\begin{array}{l}\text { Wuhan, } \\
\text { China }\end{array}$ & 508 & $\begin{array}{l}\text { The } 5 \times 10^{10} \text { viral particle vaccine was } \\
\text { safe and elicited significant immune } \\
\text { responses in the majority of recipients } \\
\text { after a single immunization }\end{array}$ & $\begin{array}{l}\text { Registered in } \\
\text { phase III } \\
\text { (NCT04526990) }^{14} \\
\text { and recruiting } \\
\text { participants }\end{array}$ & Zhu et al 82 \\
\hline $\begin{array}{l}\text { National } \\
\text { Institute of } \\
\text { Allergy and } \\
\text { Infectious } \\
\text { Diseases } \\
\text { (NIAID) }\end{array}$ & NCT04283461 & I & $\begin{array}{l}\text { An open-label } \\
\text { dose-ranging of } \\
\text { the safety and } \\
\text { immunogenicity } \\
\text { of COVID-19 } \\
\text { vaccine in } \\
\text { healthy adults } \\
\text { aged } 18 \text { years } \\
\text { and over }\end{array}$ & mRNA-1273 & $\begin{array}{l}\text { United } \\
\text { States }\end{array}$ & $\begin{array}{l}45 \\
\text { (preliminary } \\
\text { report) } 40\end{array}$ & $\begin{array}{l}\text { Its preliminary report including } 45 \\
\text { healthy adults aged } 18 \text { to } 55 \text { years, stated } \\
\text { that the vaccine induced an immune } \\
\text { response in all participants and that no } \\
\text { trial-limiting safety concerns were } \\
\text { identified. Due to the high mortality and } \\
\text { incidence of Covid- } 19 \text { in older } \\
\text { population, the trial was expanded to } \\
\text { include } 40 \text { older adults aged } 56 \text { years and } \\
\text { older. It was concluded that the } \\
\text { mRNA-1273 had mainly mild to } \\
\text { moderate adverse events in older adults } \\
\text { and that the } 100-\mu g \text { dose induced higher } \\
\text { binding- and neutralizing-antibody titers } \\
\text { than the } 25-\mu g \text { dose. }\end{array}$ & $\begin{array}{l}\text { Registered in } \\
\text { phase III } \\
\text { (NCT04470427) }^{8} \\
\text { and active not } \\
\text { recruiting }\end{array}$ & $\begin{array}{l}\text { Jackson et } \\
\text { al } 65 \\
\text { Anderson } \\
\text { et al } 83\end{array}$ \\
\hline $\begin{array}{l}\text { Beijing } \\
\text { Institute of } \\
\text { Biological } \\
\text { Products Co., } \\
\text { LTD }\end{array}$ & ChiCTR2000032459 & I/II & $\begin{array}{l}\text { A randomized, } \\
\text { double-blind, } \\
\text { placebo- } \\
\text { controlled } \\
\text { clinical trial in } \\
\text { healthy adults } \\
\text { aged } 18 \text { years } \\
\text { and older } \\
\text { (18-80 years in } \\
\text { phase I and } \\
18-59 \text { years in } \\
\text { phase II) }\end{array}$ & $\begin{array}{l}\text { Inactivated } \\
\text { vaccine } \\
\text { (BBIBP- } \\
\text { CorV) }\end{array}$ & $\begin{array}{l}\text { Henan } \\
\text { Province, } \\
\text { China }\end{array}$ & $\begin{array}{l}1192 \text { in } \\
\text { phase I } \\
2448 \text { in } \\
\text { phase II }\end{array}$ & $\begin{array}{l}\text { it was reported that the vaccine was safe, } \\
\text { well tolerated and that the two-dose } \\
\text { immunization with } 4 \mu \mathrm{g} \text { vaccine on days } 0 \\
\text { and } 21 \text { or days } 0 \text { and } 28 \text { achieved higher } \\
\text { neutralizing antibody titers than the } \\
\text { single } 8 \mu \text { g dose or } 4 \mu \text { g dose on days } 0 \\
\text { and } 14 \text {. Adverse reactions were mild or } \\
\text { moderate in severity. }\end{array}$ & - & Xia et al 59 \\
\hline Gamaleya & NCT04436471 & I/II & Two open-label, & Recombined & Russia & $76(38$ in & It was reported that the vaccine was safe & The vaccine is in & Logunov et \\
\hline
\end{tabular}




\begin{tabular}{|c|c|c|c|c|c|c|c|c|c|}
\hline $\begin{array}{l}\text { COVID-19 } \\
\text { vaccine } \\
\text { developer/ } \\
\text { Manufacturer }\end{array}$ & Identifier & Phase & $\begin{array}{l}\text { Brief } \\
\text { description }\end{array}$ & Vaccine & Country & $\begin{array}{l}\text { Number of } \\
\text { participants }\end{array}$ & Published Results & $\begin{array}{l}\text { Status of the } \\
\text { vaccine }\end{array}$ & References \\
\hline $\begin{array}{l}\text { Research } \\
\text { Institute of } \\
\text { Epidemiology } \\
\text { and } \\
\text { Microbiology, } \\
\text { Health } \\
\text { Ministry of the } \\
\text { Russian } \\
\text { Federation }\end{array}$ & NCT04437875 & & $\begin{array}{l}\text { non- } \\
\text { randomized } \\
\text { clinical trial in } \\
\text { healthy } \\
\text { volunteers aged } \\
18 \text { to } 60 \text { years, } \\
\text { aiming to assess } \\
\text { the safety and } \\
\text { immunogenicity } \\
\text { of two } \\
\text { formulations } \\
\text { (frozen and } \\
\text { lyophilized) of } \\
\text { the vaccine }\end{array}$ & $\begin{array}{l}\text { viral vector } \\
\text { vaccine } \\
\text { (rAd26 and } \\
\text { rAd5) }\end{array}$ & & each study) & $\begin{array}{l}\text { and induced strong humoral and cellular } \\
\text { immune responses in participants. The } \\
\text { most common adverse events were pain } \\
\text { at injection site (58\%), hyperthermia } \\
\text { (50\%), headache ( } 42 \% \text { ), asthenia (28\%), } \\
\text { and muscle and joint pain ( } 24 \% \text { ). Most } \\
\text { adverse events were mild and no serious } \\
\text { adverse events were detected }\end{array}$ & $\begin{array}{l}\text { phase III with five } \\
\text { clinical trials } \\
\text { (NCT04530396, } \\
\text { NCT04564716, } \\
\text { NCT04642339, } \\
\text { NCT04640233 } \\
\text { and } \\
\text { NCT04656613) } \\
7,11,38,39,41\end{array}$ & al 60 \\
\hline $\begin{array}{l}\text { University of } \\
\text { Oxford }\end{array}$ & NCT04324606 & $1 / I I$ & $\begin{array}{l}\text { Randomized, } \\
\text { single-blind, } \\
\text { phase I/II } \\
\text { clinical trial } \\
\text { controlled by a } \\
\text { meningococcal } \\
\text { vaccine, in } \\
\text { healthy adults } \\
\text { aged } 18 \text { to } 55 \\
\text { years. }\end{array}$ & $\begin{array}{l}\text { Non- } \\
\text { replicating } \\
\text { viral vector } \\
\text { (ChAdOx1 } \\
\text { nCoV-19) }\end{array}$ & $\begin{array}{l}\text { United- } \\
\text { Kingdom }\end{array}$ & 1077 & $\begin{array}{l}\text { It was reported that the ChAdOx1 } \\
\text { nCoV-19 vaccine had an acceptable } \\
\text { safety profile and that a booster dose } \\
\text { boosted antibody responses. Local and } \\
\text { systemic reactions were more common in } \\
\text { the COVID-19 vaccine group including } \\
\text { pain, feeling feverish, chills, muscle ache, } \\
\text { headache, and malaise. }\end{array}$ & $\begin{array}{l}\text { The vaccine is in } \\
\text { phase II/III } \\
\text { (NCT04400838) } \\
25 \text { and recruiting } \\
\text { participants }\end{array}$ & $\begin{array}{l}\text { Folegatti et } \\
\text { al } 61\end{array}$ \\
\hline $\begin{array}{l}\text { University of } \\
\text { Oxford }\end{array}$ & NCT0 $4400838^{25}$ & $I I / I I I$ & $\begin{array}{l}\text { A single-blind, } \\
\text { randomized, } \\
\text { controlled, in } \\
\text { healthy adults } \\
\text { aged } 18 \text { years } \\
\text { and older } \\
\text { enrolled at two } \\
\text { UK clinical } \\
\text { research } \\
\text { facilities, in an } \\
\text { age-escalation } \\
\text { manner (18-55 } \\
\text { years, 56-69 } \\
\text { years, and 70 } \\
\text { years and older } \\
\text { immunogenicity } \\
\text { subgroups) }\end{array}$ & $\begin{array}{l}\text { Non- } \\
\text { replicating } \\
\text { viral vector } \\
\text { (ChAdOx1 } \\
\text { nCoV-19) }\end{array}$ & $\begin{array}{l}\text { United- } \\
\text { Kingdom }\end{array}$ & $\begin{array}{l}560(160 \\
\text { aged } 18-55 \\
\text { years, } 160 \\
\text { aged } 56-69 \\
\text { years and } \\
240 \text { aged } \\
70 \text { years } \\
\text { and older })\end{array}$ & $\begin{array}{l}\text { The preliminary stated that ChAdOx } 1 \\
\text { nCoV-19 appears to be better tolerated } \\
\text { in older adults than younger adults. Local } \\
\text { and systemic reactions (injection-site } \\
\text { pain, feeling feverish, myalgias, headache) } \\
\text { were less common for those aged } 56 \\
\text { years and older. It was also reported that } \\
\text { the vaccine had similar immunogenicity } \\
\text { across all age groups after a booster dose. }\end{array}$ & $\begin{array}{l}\text { Recruiting } \\
\text { participants }\end{array}$ & $\begin{array}{l}\text { Ramasamy } \\
\text { et al } 84\end{array}$ \\
\hline Novavax & $\underline{\text { NCT04368988 }}$ & $1 / I I$ & $\begin{array}{l}\text { Randomized, } \\
\text { placebo- } \\
\text { controlled } \\
\text { clinical trial in } \\
\text { healthy adults }\end{array}$ & $\begin{array}{l}\text { Recombinant } \\
\text { spike protein } \\
\text { nanoparticle } \\
\text { vaccine with } \\
\text { Matrix-M1 }\end{array}$ & Australia & 131 & $\begin{array}{l}\text { The primary analysis at day } 35 \text { concluded } \\
\text { that that the vaccine appeared safe, } \\
\text { elicited immune responses that exceeded } \\
\text { levels in Covid- } 19 \text { convalescent serum } \\
\text { and that the adjuvant induced CD4+ T- }\end{array}$ & $\begin{array}{l}\text { The vaccine has } \\
\text { two phase II } \\
\text { clinical trials } \\
\text { (NCT04611802 } \\
\text { and }\end{array}$ & $\begin{array}{l}\text { Keech et al } \\
62\end{array}$ \\
\hline
\end{tabular}




\begin{tabular}{|c|c|c|c|c|c|c|c|c|c|}
\hline $\begin{array}{l}\text { COVID-19 } \\
\text { vaccine } \\
\text { developer/ } \\
\text { Manufacturer }\end{array}$ & Identifier & Phase & $\begin{array}{l}\text { Brief } \\
\text { description }\end{array}$ & Vaccine & Country & $\begin{array}{l}\text { Number of } \\
\text { participants }\end{array}$ & Published Results & $\begin{array}{l}\text { Status of the } \\
\text { vaccine }\end{array}$ & References \\
\hline & & & $\begin{array}{l}\text { aged } 18 \text { to } 59 \\
\text { years }\end{array}$ & $\begin{array}{l}\text { adjuvant } \\
\text { (NVX- } \\
\text { CoV2373) }\end{array}$ & & & $\begin{array}{l}\text { cell responses biased toward a Th1 } \\
\text { phenotype. Reactogenicity was absent or } \\
\text { mild in the majority of participants, more } \\
\text { common with adjuvant }\end{array}$ & $\frac{\text { NCT04583995) }}{19,23}$ & \\
\hline \multirow[t]{3}{*}{$\begin{array}{l}\text { BioNTch/ } \\
\text { Pfizer's }\end{array}$} & \multirow[t]{3}{*}{ NCT04368728 } & 1 & $\begin{array}{l}\text { Placebo- } \\
\text { controlled, } \\
\text { observer- } \\
\text { blinded and } \\
\text { dose escalation } \\
\text { clinical trial in } \\
\text { healthy adults } \\
\text { aged } 18 \text { to } 55 \\
\text { years and } 65 \text { to } \\
85 \text { years }\end{array}$ & $\begin{array}{l}\text { Two RNA } \\
\text { vaccines } \\
\text { (BNT162b1 } \\
\text { and } \\
\text { BNT162b2) }\end{array}$ & $\begin{array}{l}\text { United- } \\
\text { States }\end{array}$ & 195 & $\begin{array}{l}\text { The trial supported the selection of } \\
\text { BNT162b2 for advancement to a pivotal } \\
\text { phase II/III safety and efficacy evaluation }\end{array}$ & - & $\begin{array}{l}\text { Walsh et al } \\
85\end{array}$ \\
\hline & & $1 / I I$ & $\begin{array}{l}\text { Ongoing } \\
\text { placebo- } \\
\text { controlled, } \\
\text { observer- } \\
\text { blinded, dose- } \\
\text { escalation in } \\
\text { healthy adults } \\
\text { aged } 18 \text { to } 55 \\
\text { years }\end{array}$ & $\begin{array}{l}\text { RNA } \\
\text { vaccines } \\
\text { (BNT162b1) }\end{array}$ & $\begin{array}{l}\text { United- } \\
\text { States }\end{array}$ & 45 & $\begin{array}{l}\text { It reported that the vaccine exhibited a } \\
\text { tolerability and safety profile consistent } \\
\text { with those previously observed for } \\
\text { mRNA-based vaccine. Local reactions and } \\
\text { systemic events were dose-dependent, } \\
\text { generally mild to moderate, and transient. } \\
\text { However, even if there was stated that } \\
\text { there was a robust immunogenicity after } \\
\text { vaccination with BNT162b1, the findings } \\
\text { were not proof of vaccine efficacy }\end{array}$ & - & $\begin{array}{l}\text { Mulligan et } \\
\text { al }^{63}\end{array}$ \\
\hline & & $\| 1 / I I I$ & $\begin{array}{l}\text { Ongoing } \\
\text { multinational, } \\
\text { placebo- } \\
\text { controlled, } \\
\text { observer- } \\
\text { blinded clinical } \\
\text { trial in healthy } \\
\text { adults aged } 16 \\
\text { years and older }\end{array}$ & $\begin{array}{l}\text { RNA } \\
\text { vaccines } \\
\text { (BNT162b2) }\end{array}$ & $\begin{array}{l}\text { United- } \\
\text { States, } \\
\text { Argentina, } \\
\text { Brazil, } \\
\text { South } \\
\text { Africa, } \\
\text { Germany, } \\
\text { Turkey }\end{array}$ & 43548 & $\begin{array}{l}\text { The preliminary report stated that a two } \\
\text { dose regimen of BNT162b2 was } 95 \% \\
\text { ( } 95 \% \text { CI }[90.3 \%-97.6 \%] \text { ) effective against } \\
\text { Covid-19 in persons aged } 16 \text { years and } \\
\text { older. Safety over two months was similar } \\
\text { to that of other viral vaccines and was } \\
\text { characterized, especially after the second } \\
\text { dose, by mild to moderate local reactions } \\
\text { (pain, erythema, swelling) and systemic } \\
\text { reactions (fever, headache, myalgias) } \\
\text { which resolved rapidly }\end{array}$ & - & $\begin{array}{l}\text { Polack et al } \\
86\end{array}$ \\
\hline $\begin{array}{l}\text { Wuhan } \\
\text { Institute of } \\
\text { Biological } \\
\text { Products co., } \\
\text { LTD. }\end{array}$ & ChiCTR2000031809 & $\begin{array}{l}\text { I and } \\
\text { II }\end{array}$ & $\begin{array}{l}\text { Ongoing } \\
\text { randomized, } \\
\text { double-blind, } \\
\text { placebo- } \\
\text { controlled in } \\
\text { healthy adults } \\
\text { aged } 18 \text { to } 59 \\
\text { years }\end{array}$ & $\begin{array}{l}\text { Inactivated } \\
\text { vaccine }\end{array}$ & $\begin{array}{l}\text { Henan } \\
\text { Province, } \\
\text { China }\end{array}$ & $\begin{array}{l}96 \text { (phase I) } \\
224 \text { (phase } \\
\text { II) }\end{array}$ & $\begin{array}{l}\text { The interim analysis demonstrated } \\
\text { immunogenicity in patients as well as a } \\
\text { low rate of adverse reactions. The most } \\
\text { common adverse reaction was injection } \\
\text { site pain, followed by fever. No serious } \\
\text { adverse reactions were noted }\end{array}$ & $\begin{array}{l}\text { This vaccine is in } \\
\text { phase III } \\
\text { (NCTO4510207) } \\
13 \text { and recruiting } \\
\text { participants }\end{array}$ & Xia et al 66 \\
\hline BioNTech SE & NCT04380701 & I/II & An ongoing & RNA & Germany & 60 & It was reported that the vaccine was safe, & - & Sahin et al \\
\hline
\end{tabular}


COVID-19 vaccine therapeutic trials review: published results and registered protocols

\begin{tabular}{|c|c|c|c|c|c|c|c|c|c|}
\hline $\begin{array}{l}\text { COVID-19 } \\
\text { vaccine } \\
\text { developer / } \\
\text { Manufacturer }\end{array}$ & Identifier & Phase & $\begin{array}{l}\text { Brief } \\
\text { description }\end{array}$ & Vaccine & Country & $\begin{array}{l}\text { Number of } \\
\text { participants }\end{array}$ & Published Results & $\begin{array}{l}\text { Status of the } \\
\text { vaccine }\end{array}$ & References \\
\hline & & & $\begin{array}{l}\text { placebo } \\
\text { controlled, } \\
\text { observer- } \\
\text { blinded clinical } \\
\text { trial in healthy } \\
\text { adults aged } \\
\text { between } 18 \text { and } \\
55 \text { years }\end{array}$ & $\begin{array}{l}\text { vaccines } \\
\text { (BNT162b1) }\end{array}$ & & & $\begin{array}{l}\text { tolerable and had antibody response. } \\
\text { Reactogenicity was dose-dependent and } \\
\text { more pronounced after the boost dose. } \\
\text { Side effects such as fever, chills, } \\
\text { headache, muscle pain, joint pain, } \\
\text { injection site pain, and tenderness, was } \\
\text { mostly mild or moderate. The report } \\
\text { concluded that BNT162b1 induced } \\
\text { functional and proinflammatory } \\
C D 4^{+} \text {and CD } 8^{+} \mathrm{T} \text { cell responses in } \\
\text { almost all participants, with } \mathrm{T}_{H} 1 \\
\text { polarization of the helper response }\end{array}$ & & 64 \\
\hline
\end{tabular}




\section{DISCUSSION}

Since the emergence of SARS-CoV-2, the scientific community has been committed to identifying a therapeutic approach as well as a vaccine that is both effective and safe to achieve the goal of reducing morbidity and mortality attributable to COVID-19.

This review is a recent synthesis of clinical trials and published protocols regarding COVID-19 vaccination.

In total, as of January 24, 2021, there were 37 phase III clinical trials involving new candidates for the COVID-19 vaccine. The number of subjects required to be included in these trials varied between 100 and 60000 . The criteria for non-inclusion and exclusion in these phase clinical trials III were mainly children and pregnant women: none of the protocols of these trials concerned pregnant women and almost all of them didn't include persons aged less than 18 years, except for the multinational BioNTech SE/Pfizer's clinical trial where they included healthy individuals aged 12 years and over for their phase II/III. ${ }^{6}$ and ModernaTX's clinical trial including healthy adolescents aged 12 to 17 years. ${ }^{30}$ AstraZenaca's clinical trial in Russia was suspended due the occurrence of suspected unexpected serious adverse reaction at University of Oxford sponsored study, and will continue to be on hold until the approval on the Russian Ministry of health. 42

Under the hypothesis that certain other vaccines can strengthen innate immunity, thus making it possible to induce a decrease in infection by SARS CoV2, several other phase III and IV clinical trials have been launched such as BCG vaccine $(n=23)$, measles vaccines $(n=3)$ and polio vaccines $(n=3)$. At the time of writing this review, there was no publication of the results of these clinical trials.

All published clinical trials' results concerning the safety and immunogenicity of the vaccine were phases I/II and II/III with promising results concerning these two criteria. Having multiples vaccines candidates could be an advantage. In fact, in case one of them fails, there is still others under development. However, the majority of the published clinical trials' results involved a small proportion of participants, in addition to the accelerated process of COVID-19 vaccines development, these could mask some side-effects. Moreover, this rush in the manufacturing process might lead to the production of a vaccine with limited effectiveness and therefore provide immunity, complete or incomplete, only to some vaccinated individuals. ${ }^{87}$ Furthermore, published clinical trials' results involved only healthy individuals and few elderly. Even though the more vulnerable individuals, such as the elderly and those with co-morbidities would have priority for vaccines, the vaccine effectiveness and side effects are unknow in this group. ${ }^{87}$

Despite the progress made and the promising results of clinical trials of candidate vaccines, many obstacles and difficulties must be considered, in particular the logistical difficulties surrounding the mass production and the delivery of millions or even billions of doses to the world population, which will represent probably the biggest current challenge. Note that other constraints related to certain types of vaccines, such as mRNAs which are quite unstable at room temperature, requiring storage in freezers. ${ }^{88}$ Indeed almost all the new COVID-19 vaccines mentioned require cold stor- age with different requirements. The distribution of these vaccines then assumes a need for the cooperation of government and companies for cold storage and global transport. The Pfizer vaccine should be stored at a temperature of minus $70{ }^{\circ} \mathrm{C} \pm 10^{\circ} \mathrm{C}, 89,90$ the frozen Gam-COVID- vaccine (Sputnik V) requires a storage temperature of minus 18 ${ }^{\circ} \mathrm{C}$, while its lyophilized formulation should be stored at a temperature of 2 to $8{ }^{\circ} \mathrm{C} .60$ Furthermore, despite the rapid development and production of vaccines, their distribution to the most vulnerable and deprived populations and in the poorest countries remains the major issue requiring to help these groups and countries in order to benefit from the necessary and efficient logistics allowing to end this pandemic.

COVID-19 vaccine development continues at unprecedented speed, but it's uncertain that there would be enough production in 2021. New waves of SARS-CoV-2 infections are likely to occur, therefore, we will have to continue preventive measures such as social distancing, mask wearing and hand hygiene.

\section{Box 1: Vaccine development through phases of clinical trials}

Phase I : These are the first experiments in humans on a small number of healthy volunteers and focusing on the safety and immunogenicity of the vaccine

Phase II : This phase covers a larger cohort and focuses more on the immunogenicity of the vaccine, allowing the immune response to be analyzed according to age, sex, ethnicity and other variables. Efficiency can also be assessed at this stage.

Parallel phase I/II and phase II/III studies can be performed, if sufficient data has been extracted from the previous phase, to achieve ethical acceleration.

Phase IV concerns post-marketing authorization trials.

\section{ACKNOWLEDGEMENTS}

We would like to thank WHO Tunisia Office for their financial support to the open access fees of this article.

\section{FUNDING}

None

\section{AUTHORSHIP CONTRIBUTIONS}

MO performed the literature search and drafted the manuscript.

MS was responsible for the redaction and revision of the manuscript, and developed the methodology with MO.

$\mathrm{AH}$ and HL selected the clinical trials for new candidates COVID-19 vaccines and summarized it. 
SDe and HBS were responsible for the other COVID-19 vaccine part, while $\mathrm{SDh}$ and $\mathrm{CH}$ were responsible for the published clinical trials' results.

$\mathrm{LB}, \mathrm{SB}$ and NBAB critically revised the manuscript.

All authors approved the final version of the manuscript.

\section{COMPETING INTEREST}

The authors completed the Unified Competing Interest form at www.icmje.org/coi disclosure.pdf (available upon request from the corresponding author), and declare no conflicts of interest.

\section{CORRESPONDENCE TO}

Molka Osman, National Observatory of New and Emerging Diseases, Tunisia,molkaosman@gmail.com

Submitted: December 03, 2020 GMT, Accepted: February 21, 2021 GMT 


\section{REFERENCES}

1. Archived: WHO Timeline - COVID-19. Accessed January 26, 2021. https://www.who.int/news/item/2 7-04-2020-who-timeline---covid-19

2. WHO Coronavirus Disease (COVID-19) Dashboard WHO Coronavirus Disease (COVID-19) Dashboard. Accessed January 24, 2021. https://covid19.who.int/

3. Draft landscape and tracker of COVID-19 candidate vaccines. Accessed January 24, 2021. https://www.wh o.int/publications/m/item/draft-landscape-of-covid-1 9-candidate-vaccines

4. Sharpe HR, Gilbride C, Allen E, et al. The early landscape of coronavirus disease 2019 vaccine development in the UK and rest of the world. Immunology. 2020;160(3):223-232. doi:10.1111/imm.1 $\underline{3222}$

5. Wu SC. Progress and Concept for COVID-19 Vaccine Development. Biotechnol J. 2020;15(6). doi:10.1002/bi ot.202000147

6. Study to Describe the Safety, Tolerability, Immunogenicity, and Efficacy of RNA Vaccine Candidates Against COVID-19 in Healthy Individuals - Full Text View - ClinicalTrials.gov. Accessed January 26, 2021. https://clinicaltrials.gov/ct2/show/NCT0436 8728?term $=$ Sars $+\mathrm{CoV}+2$ \&cond=Covid $-19 \&$ intr $=$ Vacci ne \&phase $=23 \&$ draw $=2 \&$ rank $=43$

7. Clinical Trial of Efficacy, Safety, and Immunogenicity of Gam-COVID-Vac Vaccine Against COVID-19 - Full Text View - ClinicalTrials.gov. Accessed January 25, 2021. https://clinicaltrials.gov/c t2/show/NCT04530396?term $=$ Sars $+\mathrm{CoV}+2 \&$ cond $=\mathrm{Cov}$ id-19\&intr=Vaccine \&phase $=23$ \&draw $=2$ \&rank $=25$

8. A Study to Evaluate Efficacy, Safety, and Immunogenicity of mRNA-1273 Vaccine in Adults Aged 18 Years and Older to Prevent COVID-19 - Full Text View - ClinicalTrials.gov. Accessed January 26, 2021. https://clinicaltrials.gov/ct2/show/NCT0447042 7?term $=$ Sars $+\mathrm{CoV}+2$ \&cond $=$ Covid -19 \&intr=Vaccin e \&phase $=23 \&$ draw $=2$

9. Clinical Trial to Evaluate the Efficacy, Immunogenicity and Safety of the Inactivated SARSCoV-2 Vaccine (COVID-19) - Full Text View ClinicalTrials.gov. Accessed January 24, 2021. http s://clinicaltrials.gov/ct2/show/NCT04560881?term=Sa $\underline{\mathrm{rs}}+\mathrm{CoV}+2$ \&cond=Covid-19\&intr=Vaccine \&phase $=2$ 3\&draw $=2$ \&rank $=1$
10. Clinical Trial of Recombinant Novel Coronavirus Vaccine (Adenovirus Type 5 Vector) Against COVID-19 - Full Text View - ClinicalTrials.gov. Accessed January 26, 2021. https://clinicaltrials.gov/c t2/show/NCT04540419?term $=$ Sars $+\mathrm{CoV}+2 \&$ cond $=\mathrm{Cov}$ id-19\&intr=Vaccine \&phase $=23 \& d$ raw $=2$

11. Clinical Trial of Efficacy, Safety, and Immunogenicity of Gam-COVID-Vac Vaccine Against COVID-19 in Belarus - Full Text View -

ClinicalTrials.gov. Accessed January 25, 2021. http s://clinicaltrials.gov/ct2/show/NCT04564716?term=Sa $\mathrm{rs}+\mathrm{CoV}+2 \&$ cond $=$ Covid-19\&intr $=$ Vaccine \&phase $=2$ $\underline{3 \& d r a w}=2 \&$ rank $=22$

12. A Study of Ad26.COV2.S for the Prevention of SARS-CoV-2-Mediated COVID-19 in Adult Participants - Full Text View - ClinicalTrials.gov. Accessed January 26, 2021. https://clinicaltrials.gov/c t2/show/NCT04505722?term $=$ Sars $+\mathrm{CoV}+2 \&$ cond $=\mathrm{Cov}$ id-19\&intr $=$ Vaccine \&phase $=23 \&$ draw $=2$

13. A Study to Evaluate The Efficacy, Safety and Immunogenicity of Inactivated SARS-CoV-2 Vaccines (Vero Cell) in Healthy Population Aged 18 Years Old and Above - Full Text View - ClinicalTrials.gov. Accessed January 24, 2021. https://clinicaltrials.gov/c t2/show/NCT04510207?term $=$ Sars $+\mathrm{CoV}+2 \&$ cond $=\mathrm{Cov}$ id-19\&intr $=$ Vaccine \&phase $=23 \& d$ raw $=2 \&$ rank $=2$

14. Phase III Trial of A COVID-19 Vaccine of Adenovirus Vector in Adults 18 Years Old and Above Full Text View - ClinicalTrials.gov. Accessed January 26, 2021. https://clinicaltrials.gov/ct2/show/NCT0452 6990?term $=$ Sars $+\mathrm{CoV}+2$ \&cond $=$ Covid-19\&intr $=$ Vacci ne\&phase $=23 \&$ draw $=2$

15. A Study to Determine the Safety and Efficacy of SARS-CoV-2 mRNA Vaccine CVnCoV in Adults for COVID-19 - Full Text View - ClinicalTrials.gov.

Accessed January 26, 2021. https://clinicaltrials.gov/c t2/show/NCT04652102?term $=$ Sars $+\mathrm{CoV}+2 \&$ cond $=\mathrm{Cov}$ id-19\&intr=Vaccine \&phase $=23 \&$ draw $=2$

16. The Efficacy, Safety and Immunogenicity Study of Inactivated SARS-CoV-2 Vaccine for Preventing Against COVID-19 - Full Text View -

ClinicalTrials.gov. Accessed January 25, 2021. http s://clinicaltrials.gov/ct2/show/NCT04659239?term $=$ Sa $\underline{\mathrm{rs}}+\mathrm{CoV}+2$ \&cond $=$ Covid-19\&intr $=$ Vaccine \&phase $=2$ $\underline{3 \& d r a w}=2 \&$ rank $=5$

17. Phase III Double-blind, Placebo-controlled Study of AZD1222 for the Prevention of COVID-19 in Adults - Full Text View - ClinicalTrials.gov. Accessed January 26, 2021. https://clinicaltrials.gov/ct2/show/NCT0451 6746?term $=$ Sars $+\mathrm{CoV}+2 \&$ cond $=$ Covid $-19 \&$ intr $=$ Vacci ne \&phase $=23 \&$ draw $=2$ \&rank $=42$ 
18. Study of a Recombinant Coronavirus-Like Particle COVID-19 Vaccine in Adults - Full Text View ClinicalTrials.gov. Accessed January 26, 2021. http s://clinicaltrials.gov/ct2/show/NCT04636697?term $=$ Sa $\underline{\mathrm{rs}}+\mathrm{CoV}+2 \& \mathrm{cond}=$ Covid-19\&intr $=$ Vaccine \&phase $=2$ 3\&draw $=2$

19. A Study Looking at the Efficacy, Immune Response, and Safety of a COVID-19 Vaccine in Adults at Risk for SARS-CoV-2 - Full Text View ClinicalTrials.gov. Accessed January 26, 2021. http s://clinicaltrials.gov/ct2/show/NCT04611802?term=Sa $\underline{\mathrm{rs}+\mathrm{CoV}+2 \text { \&cond }=\text { Covid-19\&intr }=\text { Vaccine \&phase }=2}$ $\underline{3 \& d r a w}=2$

20. A Study of Ad26.COV2.S for the Prevention of SARS-CoV-2-mediated COVID-19 in Adults - Full Text View - ClinicalTrials.gov. Accessed January 26, 2021. https://clinicaltrials.gov/ct2/show/NCT0461494 8?term $=$ Sars $+\mathrm{CoV}+2 \&$ cond $=$ Covid -19 \&intr $=$ Vaccin e \&phase $=23 \&$ draw $=2 \&$ rank $=63$

21. A Phase III Clinical Trial to Determine the Safety and Efficacy of ZF2001 for Prevention of COVID-19 Full Text View - ClinicalTrials.gov. Accessed January 25, 2021. https://clinicaltrials.gov/ct2/show/NCT0464 6590?term $=$ Sars $+\mathrm{CoV}+2$ \&cond $=$ Covid -19 \&intr $=$ Vacci ne \&phase $=23 \&$ draw $=2$

22. An Efficacy and Safety Clinical Trial of an Investigational COVID-19 Vaccine (BBV152) in Adult Volunteers - Full Text View - ClinicalTrials.gov. Accessed January 26, 2021. https://clinicaltrials.gov/c t2/show/NCT04641481?term=Sars $+\mathrm{CoV}+2$ \&cond=Cov id-19\&intr $=$ Vaccine \&phase $=23 \&$ draw $=2$

23. A Study Looking at the Effectiveness, Immune Response, and Safety of a COVID-19 Vaccine in Adults in the United Kingdom - Full Text View ClinicalTrials.gov. Accessed January 25, 2021. http s://clinicaltrials.gov/ct2/show/NCT04583995?term=Sa

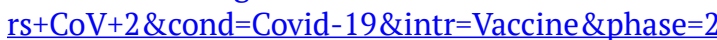
3\&draw $=2$

24. Clinical Trial For SARS-CoV-2 Vaccine (COVID-19) - Full Text View - ClinicalTrials.gov. Accessed January 25, 2021. https://clinicaltrials.gov/c t2/show/NCT04582344?term=Sars $+\mathrm{CoV}+2 \&$ cond $=\mathrm{Cov}$ id-19\&intr $=$ Vaccine \&phase $=23 \&$ draw $=2$

25. Investigating a Vaccine Against COVID-19 - Full Text View - ClinicalTrials.gov. Accessed January 26, 2021. https://clinicaltrials.gov/ct2/show/NCT0440083 $\underline{\text { 8} \text { term }}=\mathrm{Sars}+\mathrm{CoV}+2 \&$ cond $=$ Covid -19 \&intr $=$ Vaccin e \&phase $=23 \&$ draw $=2$ \& rank $=53$
26. Clinical Trial of Efficacy and Safety of Sinovac's Adsorbed COVID-19 (Inactivated) Vaccine in Healthcare Professionals - Full Text View ClinicalTrials.gov. Accessed January 25, 2021. http s://clinicaltrials.gov/ct2/show/NCT04456595?term=Sa $\underline{\text { rs }}+\mathrm{CoV}+2$ \&cond $=$ Covid-19\&intr $=$ Vaccine \&phase $=2$ $3 \&$ draw $=2$ \&rank $=10$

27. A Study of a Candidate COVID-19 Vaccine (COV003) - Full Text View - ClinicalTrials.gov. Accessed January 26, 2021. https://clinicaltrials.gov/c t2/show/NCT04536051?term $=\mathrm{Sars}+\mathrm{CoV}+2 \&$ cond $=\mathrm{Cov}$ $\underline{\text { id-19\&intr }=\text { Vaccine } \& \text { phase }=23 \& \text { draw }=2}$

28. Efficacy, Safety and Immunogenicity of Inactivated SARS-CoV-2 Vaccines (Vero Cell) in Healthy Adult Population In Peru - Full Text View ClinicalTrials.gov. Accessed January 24, 2021. http s://clinicaltrials.gov/ct2/show/NCT04612972?term=Sa $\underline{\mathrm{rs}}+\mathrm{CoV}+2$ \&cond $=$ Covid-19\&intr $=$ Vaccine \&phase $=2$ 3 \&draw $=2$ \&rank $=3$

29. Immunogenicity, Efficacy and Safety of QazCovidin ${ }^{\circledR}$ COVID-19 Vaccine - Full Text View ClinicalTrials.gov. Accessed January 25, 2021. http s://clinicaltrials.gov/ct2/show/NCT04691908?term=Sa $\underline{\text { rs }+\mathrm{CoV}+2 \& \text { cond }=\text { Covid }-19 \& \text { intr }=\text { Vaccine \&phase }=2}$ $\underline{3 \& d r a w}=2$

30. A Study to Evaluate the Safety, Reactogenicity, and Effectiveness of mRNA-1273 Vaccine in Adolescents 12 to < 18 Years Old to Prevent COVID-19 - Full Text View - ClinicalTrials.gov. Accessed January 26, 2021. https://clinicaltrials.gov/ct2/show/NCT0464 9151?term $=$ Sars $+\mathrm{CoV}+2 \&$ cond $=$ Covid-19\&intr $=$ Vacci ne $\&$ phase $=23 \&$ draw $=2$

31. A Study to Evaluate the Safety and Immunogenicity of Vaccine CVnCoV in Healthy Adults in Germany for COVID-19 - Full Text View ClinicalTrials.gov. Accessed January 25, 2021. http s://clinicaltrials.gov/ct2/show/NCT04674189?term=Sa $\underline{\text { rs }}+\mathrm{CoV}+2 \&$ cond $=$ Covid -19 \&intr $=$ Vaccine \&phase $=2$ $3 \&$ draw $=2$

32. Efficacy, Safety, and Immunogenicity of an Inactivated Vaccine Against COVID-19 in High Infection Risk Adults - Full Text View ClinicalTrials.gov. Accessed January 24, 2021. http s://clinicaltrials.gov/ct2/show/NCT04651790?term $=$ Sa $\mathrm{rs}+\mathrm{CoV}+2$ \&cond $=$ Covid- 19 \&intr $=$ Vaccine \&phase $=2$ $\underline{3 \& d r a w}=2$

33. Efficacy, Safety and Immunogenicity Study of SARS-CoV-2 Inactivated Vaccine - Full Text View ClinicalTrials.gov. Accessed January 25, 2021. http s://clinicaltrials.gov/ct2/show/NCT04508075?term $=$ Sa $\underline{\mathrm{rs}}+\mathrm{CoV}+2$ \&cond $=$ Covid-19 \&intr=Vaccine \&phase $=2$ $\underline{3 \& d r a w=2 \& \text { rank }=12}$ 
34. Study of the Commercial Scale SARS-CoV-2 Vaccine Against the Pilot Scale Among Adults, and Bridging Study of the Immunogenicity in Elderly Against That in Adults - Full Text View -

ClinicalTrials.gov. Accessed January 25, 2021. http s://clinicaltrials.gov/ct2/show/NCT04617483?term=Sa $\underline{\mathrm{rs}}+\mathrm{CoV}+2$ \&cond $=$ Covid-19\&intr $=$ Vaccine \&phase $=2$ $3 \&$ draw $=2$ \&rank $=11$

35. Phase II / III Study of COVID-19 DNA Vaccine (AG0302-COVID19) - Full Text View -

ClinicalTrials.gov. Accessed January 26, 2021. http s://clinicaltrials.gov/ct2/show/NCT04655625?term $=$ Sa $\underline{\mathrm{rs}}+\mathrm{CoV}+2$ \&cond=Covid-19\&intr $=$ Vaccine \&phase $=2$ $3 \&$ draw $=2$

36. A Controlled Phase 2/3 Study of Adjuvanted Recombinant SARS-CoV-2 Trimeric S-protein Vaccine (SCB-2019) for the Prevention of COVID-19 - Full Text View - ClinicalTrials.gov. Accessed January 26, 2021. https://clinicaltrials.gov/ct2/show/NCT0467239 5?term $=$ Sars $+\mathrm{CoV}+2 \&$ cond $=$ Covid -19 \&intr $=$ Vaccin e \&phase $=23 \&$ draw $=2 \&$ rank $=36$

37. A Study to Evaluate the Safety, Immunogenicity, and Efficacy of UB-612 COVID-19 Vaccine - Full Text View - ClinicalTrials.gov. Accessed January 26, 2021. https://clinicaltrials.gov/ct2/show/NCT04683224?ter $\underline{m}=$ Sars $+\mathrm{CoV}+2 \&$ cond=Covid -19 \&intr=Vaccine \&phas $\underline{\mathrm{e}=23 \text { \&draw }=2 \text { \&rank }=61}$

38. Clinical Trial of the Immunogenicity, Safety, and Efficacy of the Gam-COVID-Vac Vaccine Against COVID-19 in Venezuela - Full Text View -

ClinicalTrials.gov. Accessed January 25, 2021. http s://clinicaltrials.gov/ct2/show/NCT04642339?term=Sa $\underline{\mathrm{rs}}+\mathrm{CoV}+2$ \&cond=Covid-19\&intr=Vaccine \&phase $=2$ 3\&draw=2\&rank=16

39. Clinical Trial to Assess Safety and Immunogenicity of Gam-COVID-Vac Combined Vector Vaccine for Severe Acute Respiratory Syndrome Coronavirus 2 (SARS-Cov-2) Infection Full Text View - ClinicalTrials.gov. Accessed January 26, 2021. https://clinicaltrials.gov/ct2/show/NCT0464 0233?term $=$ Sars $+\mathrm{CoV}+2$ \&cond $=$ Covid -19 \&intr $=$ Vacci ne \&phase $=23 \&$ draw $=2 \&$ rank $=44$

40. Study to Evaluate the Lot Consistency, Safety, Tolerability, and Immunogenicity of BNT162b2 Against COVID-19 in Healthy Adults - Full Text View - ClinicalTrials.gov. Accessed January 26, 2021. http s://clinicaltrials.gov/ct2/show/NCT04713553?term=Sa $\underline{\mathrm{rs}}+\mathrm{CoV}+2 \& \mathrm{cond}=$ Covid -19 \&intr $=$ Vaccine \&phase $=2$ $3 \&$ draw $=2$
41. A Phase III Clinical Trial of the Immunogenicity and Safety of the Gam-COVID-Vac Vaccine Against COVID-19 in the UAE - Tabular View -

ClinicalTrials.gov. Accessed January 25, 2021. http s://clinicaltrials.gov/ct2/show/record/NCT04656613?t erm $=$ Sars $+\mathrm{CoV}+2 \&$ cond $=$ Covid $-19 \&$ intr $=$ Vaccine \&ph ase $=23 \&$ draw $=2$

42. AZD1222 Vaccine for the Prevention of COVID-19 - Full Text View - ClinicalTrials.gov. Accessed January 26, 2021. https://clinicaltrials.gov/ct2/show/NCT0454 0393?term $=$ Sars $+\mathrm{CoV}+2 \&$ cond=Covid -19 \&intr $=$ Vacci ne \&phase $=23$ \&draw $=2$ \&rank $=35$

43. CROWN CORONATION: COVID-19 Research Outcomes Worldwide Network for CORONAvirus prevenTION - Full Text View - ClinicalTrials.gov. Accessed January 26, 2021. https://clinicaltrials.gov/c t2/show/study/NCT04333732?term $=$ Sars $+\mathrm{CoV}+2 \&$ con

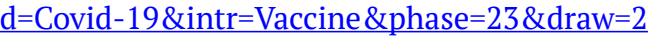

44. Use of a Live Attenuated Vaccine as an Immunebased Preventive Against COVID-19-associated Sepsis - Full Text View - ClinicalTrials.gov. Accessed January 26, 2021. https://clinicaltrials.gov/ct2/show/NCT0447 5081?term $=$ Sars + CoV $+2 \&$ cond $=$ Covid $-19 \&$ intr $=$ Vacci ne \&phase $=23 \& d r a w=2$

45. Measles Vaccine in HCW - Full Text View ClinicalTrials.gov. Accessed January 25, 2021. http s://clinicaltrials.gov/ct2/show/NCT04357028?term $=$ Sa $\underline{\mathrm{rs}}+\mathrm{CoV}+2$ \&cond $=$ Covid -19 \&intr $=$ Vaccine \&phase $=2$ $\underline{3 \& \text { draw }=2 \& \text { rank }=9}$

46. OPV as Potential Protection Against COVID-19 Full Text View - ClinicalTrials.gov. Accessed January 26, 2021. https://clinicaltrials.gov/ct2/show/NCT0444 5428?term $=$ Sars $+\mathrm{CoV}+2 \&$ cond $=$ Covid -19 \&intr $=$ Vacci ne \&phase $=23 \&$ draw $=2 \&$ rank $=54$

47. Polio Vaccine (IPV) for SARS-CoV-2 and Prevention of Coronavirus Disease (COVID-19) - Full Text View - ClinicalTrials.gov. Accessed January 25, 2021. https://clinicaltrials.gov/ct2/show/study/NCT04 639375?term $=$ Sars $+\mathrm{CoV}+2$ \&cond $=$ Covid -19 \&intr $=\mathrm{Vac}$ cine \&phase $=23 \&$ draw $=2$

48. A Phase 3 Randomized Double Blind Efficacy and Safety Study of Oral Polio Vaccine and NA-831 for Covid-19 - Full Text View - ClinicalTrials.gov. Accessed January 26, 2021. https://clinicaltrials.gov/c t2/show/NCT04540185?term $=$ Sars $+\mathrm{CoV}+2 \&$ cond $=\mathrm{Cov}$ id-19\&intr $=$ Vaccine \&phase $=23$ \&draw $=2$ \&rank $=37$

49. Reducing COVID-19 Related Hospital Admission in Elderly by BCG Vaccination - Full Text View ClinicalTrials.gov. Accessed January 25, 2021. http s://clinicaltrials.gov/ct2/show/NCT04417335?term=Sa $\underline{\mathrm{rs}}+\mathrm{CoV}+2 \&$ cond $=$ Covid -19 \&intr $=$ Vaccine \&phase $=2$ $\underline{3 \& \text { draw }=2 \text { \&rank }=15}$ 
50. Prevention Of Respiratory Tract Infection And Covid-19 Through BCG Vaccination In Vulnerable Older Adults - Full Text View - ClinicalTrials.gov. Accessed January 26, 2021. https://clinicaltrials.gov/c t2/show/NCT04537663

51. BCG Vaccine for Health Care Workers as Defense Against COVID 19 - Full Text View -

ClinicalTrials.gov. Accessed January 26, 2021. http s://clinicaltrials.gov/ct2/show/NCT04348370?term=Sa $\underline{\text { rs }+C o V+2 \& \text { cond }=\text { Covid }-19 \text { \&intr }=\text { Vaccine \&phase }=2}$ $3 \&$ draw $=2$

52. BCG to Reduce Absenteeism Among Health Care Workers During the COVID-19 Pandemic - Full Text View - ClinicalTrials.gov. Accessed January 26, 2021. https://clinicaltrials.gov/ct2/show/NCT04641858?ter $\underline{m}=$ Sars $+\mathrm{CoV}+2$ \&cond $=$ Covid -19 \&intr $=$ Vaccine \&phas $\mathrm{e}=23 \&$ draw $=2$

53. COVID-19: BCG As Therapeutic Vaccine, Transmission Limitation, and Immunoglobulin Enhancement - Full Text View - ClinicalTrials.gov. Accessed January 25, 2021. https://clinicaltrials.gov/c t2/show/NCT04369794?term=Sars + CoV $+2 \&$ cond $=$ Cov id-19\&intr $=$ Vaccine \&phase $=23 \& d$ raw $=2$

54. Bacillus Calmette-guérin Vaccination to Prevent COVID-19 - Full Text View - ClinicalTrials.gov. Accessed January 25, 2021. https://clinicaltrials.gov/c t2/show/NCT04414267?term $=$ Sars $+\mathrm{CoV}+2 \&$ cond $=\mathrm{Cov}$ id-19\&intr $=$ Vaccine \&phase $=23 \&$ draw $=2$

55. Reducing Health Care Workers Absenteeism in Covid-19 Pandemic Through BCG Vaccine - Full Text View - ClinicalTrials.gov. Accessed January 25, 2021. https://clinicaltrials.gov/ct2/show/NCT04328441?ter $\mathrm{m}=$ Sars $+\mathrm{CoV}+2 \&$ cond $=$ Covid -19 \&intr $=$ Vaccine \&phas $\mathrm{e}=23$ \&draw $=2$

56. Prevention, Efficacy and Safety of BCG Vaccine in COVID-19 Among Healthcare Workers - Full Text View - ClinicalTrials.gov. Accessed January 25, 2021. https://clinicaltrials.gov/ct2/show/NCT04461379?ter $\underline{m}=$ Sars $+\mathrm{CoV}+2$ \&cond $=$ Covid -19 \&intr $=$ Vaccine \&phas $\mathrm{e}=23 \&$ draw $=2$

57. Study to Assess VPM1002 in Reducing Healthcare Professionals' Absenteeism in COVID-19 Pandemic Full Text View - ClinicalTrials.gov. Accessed January 26, 2021. https://clinicaltrials.gov/ct2/show/NCT0438 7409?term $=$ Sars $+\mathrm{CoV}+2$ \& cond $=$ Covid -19 \&intr $=$ Vacci ne $\&$ phase $=23 \&$ draw $=2$ \&rank $=71$

58. Performance Evaluation of BCG Vaccination in Healthcare Personnel to Reduce the Severity of COVID-19 Infection. - Full Text View -

ClinicalTrials.gov. Accessed January 25, 2021. http s://clinicaltrials.gov/ct2/show/NCT04362124?term=Sa

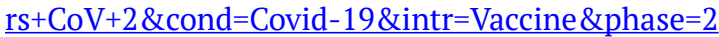
$\underline{3 \& \text { draw }=2 \& \text { rank }=6}$
59. Xia S, Zhang Y, Wang Y, et al. Safety and immunogenicity of an inactivated SARS-CoV-2 vaccine, BBIBP-CorV: a randomised, double-blind, placebo-controlled, phase 1/2 trial. Lancet Infect Dis. 2021;21(1):39-51. doi:10.1016/S1473-3099(20)3083 1-8

60. Logunov DY, Dolzhikova I, Zubkova O, et al. Safety and immunogenicity of an rAd26 and rAd5 vectorbased heterologous prime-boost COVID-19 vaccine in two formulations: two open, non-randomised phase $1 / 2$ studies from Russia. Lancet. 2020;396(10255):887-897. doi:10.1016/S0140-6736(2 0)31866-3

61. Folegatti PM, Ewer KJ, Aley PK, et al. Safety and immunogenicity of the ChAdOx1 $\mathrm{nCoV}-19$ vaccine against SARS-CoV-2: a preliminary report of a phase $1 / 2$, single-blind, randomised controlled trial. Lancet. 2020;396(10249):467-478. doi:10.1016/S0140-6736(2 0)31604-4

62. Keech C, Albert G, Cho I, et al. Phase 1-2 Trial of a SARS-CoV-2 Recombinant Spike Protein Nanoparticle Vaccine. $N$ Engl J Med. 2020;383(24):2320-2332. doi:10.1056/nejmoa2026920

63. Mulligan MJ, Lyke KE, Kitchin N, et al. Phase I/II study of COVID-19 RNA vaccine BNT162b1 in adults. Nature. 2020;586(7830):589-593. doi:10.1038/s4158 6-020-2639-4

64. Sahin U, Muik A, Derhovanessian E, et al. COVID-19 vaccine BNT162b1 elicits human antibody and TH1 T cell responses. Nature. 2020;586(7830):594-599. doi:10.1038/s41586-020-28 14-7

65. Jackson LA, Anderson EJ, Rouphael NG, et al. An mRNA Vaccine against SARS-CoV-2 - Preliminary Report. N Engl J Med. 2020;383(20):1920-1931. doi:1 $\underline{0.1056 / \text { nejmoa2022483 }}$

66. Xia S, Duan K, Zhang Y, et al. Effect of an Inactivated Vaccine Against SARS-CoV-2 on Safety and Immunogenicity Outcomes: Interim Analysis of 2 Randomized Clinical Trials. JAMA - J Am Med Assoc. 2020;324(10):951-960. doi:10.1001/jama.2020.15543

67. Zhu FC, Li YH, Guan XH, et al. Safety, tolerability, and immunogenicity of a recombinant adenovirus type- 5 vectored COVID-19 vaccine: a dose-escalation, open-label, non-randomised, first-in-human trial. Lancet. 2020;395(10240):1845-1854. doi:10.1016/S01 40-6736(20)31208-3

68. Pagliusi S, Jarrett S, Hayman B, et al. Emerging manufacturers engagements in the COVID -19 vaccine research, development and supply. Vaccine. 2020;38(34):5418-5423. doi:10.1016/j.vaccine.2020.0 $\underline{6.022}$ 
69. BCG Vaccination to Protect Healthcare Workers Against COVID-19 - Full Text View -

ClinicalTrials.gov. Accessed January 26, 2021. http s://clinicaltrials.gov/ct2/show/NCT04327206

70. Efficacy and Safety of VPM1002 in Reducing SARS-CoV-2 (COVID-19) Infection Rate and Severity Full Text View - ClinicalTrials.gov. Accessed January 26, 2021. https://clinicaltrials.gov/ct2/show/NCT0443 9045? term $=$ Sars $+\mathrm{CoV}+2$ \& cond $=$ Covid -19 \&intr $=$ Vacci $\underline{\text { ne } \& \text { phase }}=23 \&$ draw $=2 \&$ rank $=68$

71. BCG Vaccine in Reducing Morbidity and Mortality in Elderly Individuals in COVID-19 Hotspots - Full Text View - ClinicalTrials.gov. Accessed January 26, 2021. https://clinicaltrials.gov/ct2/show/NCT0447530 $\underline{2}$

72. Study to Assess VPM1002 in Reducing Hospital Admissions and/or Severe Respiratory Infectious Diseases in Elderly in COVID-19 Pandemic - Full Text View - ClinicalTrials.gov. Accessed January 26, 2021. https://clinicaltrials.gov/ct2/show/NCT04435379?ter $\underline{m}=$ Sars $+\mathrm{CoV}+2$ \& cond $=$ Covid -19 \&intr $=$ Vaccine \&phas $\mathrm{e}=23$ \&draw $=2$ \&rank $=72$

73. Using BCG to Protect Senior Citizens During the COVID-19 Pandemic - Full Text View -

ClinicalTrials.gov. Accessed January 26, 2021. http s://clinicaltrials.gov/ct2/show/NCT04542330?term=Sa $\underline{\mathrm{rs}}+\mathrm{CoV}+2 \&$ cond $=$ Covid -19 \&intr $=$ Vaccine \&phase $=2$ $3 \&$ draw $=2$ \&rank $=60$

74. Using BCG Vaccine to Protect Health Care Workers in the COVID-19 Pandemic - Full Text View ClinicalTrials.gov. Accessed January 26, 2021. http s://clinicaltrials.gov/ct2/show/NCT04373291?term=Sa $\underline{\mathrm{rs}}+\mathrm{CoV}+2 \&$ cond $=$ Covid -19 \&intr $=$ Vaccine \&phase $=2$ $\underline{3 \& d r a w}=2$

75. Efficacy of BCG Vaccination in the Prevention of COVID19 Via the Strengthening of Innate Immunity in Health Care Workers - Full Text View -

ClinicalTrials.gov. Accessed January 26, 2021. http s://clinicaltrials.gov/ct2/show/NCT04384549?term=Sa $\underline{\text { rs }+\mathrm{CoV}+2 \& \text { cond }=\text { Covid }-19 \text { \&intr }=\text { Vaccine \&phase }=2}$ $3 \&$ draw $=2$

76. Clinical Trial Evaluating the Effect of BCG Vaccination on the Incidence and Severity of SARSCoV-2 Infections Among Healthcare Professionals During the COVID-19 Pandemic in Poland - Full Text View - ClinicalTrials.gov. Accessed January 25, 2021. https://clinicaltrials.gov/ct2/show/study/NCT0464880 0 ?term $=$ Sars $+\mathrm{CoV}+2$ \&cond $=$ Covid -19 \&intr $=$ Vaccin e\&phase $=23 \&$ draw $=2$

77. BCG Vaccination to Prevent COVID-19 - Full Text View - ClinicalTrials.gov. Accessed January 25, 2021. https://clinicaltrials.gov/ct2/show/NCT04632537?ter $\underline{m}=$ Sars $+\mathrm{CoV}+2$ \&cond $=$ Covid -19 \&intr=Vaccine \&phas $\mathrm{e}=23 \&$ draw $=2$ \&rank $=8$
78. BCG Vaccination for Healthcare Workers in COVID-19 Pandemic - Full Text View -

ClinicalTrials.gov. Accessed January 25, 2021. http s://clinicaltrials.gov/ct2/show/NCT04379336?term=Sa $\underline{\text { rs }}+\mathrm{CoV}+2$ \&cond $=$ Covid -19 \&intr $=$ Vaccine $\&$ phase $=2$ $3 \&$ draw $=2$

79. Clinical Trial to Evaluate the Efficacy of RUTI ${ }^{\circledR}$ Against SARS-COV-2 Infection (COVID-19) in Healthcare Workers - Full Text View -

ClinicalTrials.gov. Accessed January 25, 2021. http s://clinicaltrials.gov/ct2/show/NCT04453488?term=Sa $\underline{\mathrm{rs}}+\mathrm{CoV}+2$ \&cond $=$ Covid -19 \&intr $=$ Vaccine \&phase $=2$ $\underline{3 \& d r a w}=2$

80. BCG Against Covid-19 for Prevention and Amelioration of Severity Trial (BAC to the PAST) Full Text View - ClinicalTrials.gov. Accessed January 25, 2021. https://clinicaltrials.gov/ct2/show/NCT0453 4803?term $=$ Sars $+\mathrm{CoV}+2 \&$ cond $=$ Covid $-19 \&$ intr $=$ Vacci ne \&phase $=23 \&$ draw $=2 \&$ rank $=23$

81. Application of BCG Vaccine for Immuneprophylaxis Among Egyptian Healthcare Workers During the Pandemic of COVID-19 - Full Text View ClinicalTrials.gov. Accessed January 25, 2021. http s://clinicaltrials.gov/ct2/show/NCT04350931?term=Sa $\underline{\mathrm{rs}}+\mathrm{CoV}+2$ \&cond $=$ Covid -19 \&intr $=$ Vaccine \&phase $=2$ $\underline{3 \& d r a w}=2$

82. Zhu FC, Guan XH, Li YH, et al. Immunogenicity and safety of a recombinant adenovirus type-5-vectored COVID-19 vaccine in healthy adults aged 18 years or older: a randomised, double-blind, placebo-controlled, phase 2 trial. Lancet. 2020;396(10249):479-488. doi:10.1016/S0140-6736(2 0)31605-6

83. Anderson EJ, Rouphael NG, Widge AT, et al. Safety and Immunogenicity of SARS-CoV-2 mRNA-1273 Vaccine in Older Adults. $N$ Engl J Med. 2020;383(25):2427-2438. doi:10.1056/nejmoa2028436

84. Ramasamy MN, Minassian AM, Ewer KJ, et al. Safety and immunogenicity of ChAdOx1 nCoV-19 vaccine administered in a prime-boost regimen in young and old adults (COV002): a single-blind, randomised, controlled, phase 2/3 trial. Lancet. 2020;396(10267):1979-1993. doi:10.1016/S0140-673 6(20)32466-1

85. Walsh EE, Frenck RW, Falsey AR, et al. Safety and Immunogenicity of Two RNA-Based Covid-19 Vaccine Candidates. N Engl J Med. 2020;383(25):2439-2450. do i:10.1056/nejmoa2027906

86. Polack FP, Thomas SJ, Kitchin N, et al. Safety and Efficacy of the BNT162b2 mRNA Covid-19 Vaccine. $N$ Engl J Med. 2020;383(27):2603-2615. doi:10.1056/nei $\underline{\operatorname{moa} 2034577}$ 
87. Sharma O, Sultan AA, Ding H, Triggle CR. A Review of the Progress and Challenges of Developing a Vaccine for COVID-19. Front Immunol. 2020;11:585354. doi:10.3389/fimmu.2020.585354

88. DeFrancesco L. Whither COVID-19 vaccines? Nat Biotechnol. 2020;38(10):1132-1145. doi:10.1038/s4158 7-020-0697-7
89. COVID-19 Vaccine U.S. Distribution Fact Sheet | Pfizer. Accessed February 18, 2021. https://www.pfize r.com/news/hot-topics/covid_19_vaccine_u_s_distribut ion_fact_sheet

90. Pfizer-BioNTech COVID-19 Vaccine Information | CDC. Accessed February 18, 2021. https://www.cdc.go v/vaccines/covid-19/info-by-product/pfizer/index.ht $\underline{\mathrm{ml}}$ 